\title{
The GABRG2 Mutation, Q351X, Associated with Generalized Epilepsy with Febrile Seizures Plus, Has Both Loss of Function and Dominant-Negative Suppression
}

\author{
Jing-Qiong Kang, ${ }^{1}$ Wangzhen Shen, ${ }^{1}$ and Robert L. Macdonald ${ }^{1,2,3}$ \\ Departments of ${ }^{1}$ Neurology, ${ }^{2}$ Molecular Physiology and Biophysics, and ${ }^{3}$ Pharmacology, Vanderbilt University Medical Center, Nashville, Tennessee 37212
}

The $\mathrm{GABA}_{\mathrm{A}}$ receptor $\gamma 2$ subunit mutation, Q351X, associated with generalized epilepsy with febrile seizures plus (GEFS + ), created a loss of function with homozygous expression. However, heterozygous $\gamma 2(+/-)$ gene deletion mice are seizure free, suggesting that the loss of one GABRG2 allele alone in heterozygous patients may not be sufficient to produce epilepsy. Here we show that the mutant $\gamma 2$ subunit was immature and retained in the endoplasmic reticulum (ER). With heterozygous coexpression of $\gamma 2 \mathrm{~S} / \gamma 2 \mathrm{~S}(\mathrm{Q} 351 \mathrm{X})$ subunits and $\alpha 1$ and $\beta 2$ subunits, the trafficking deficient mutant $\gamma 2$ subunit reduced trafficking of wild-type partnering subunits, which was not seen in the hemizygous gene deletion control. Consequently, the function of the heterozygous receptor channel was reduced to less than the hemizygous control and to less than half of the wild-type receptors with a full gene dose. Pulse-chase experiments demonstrated that in the presence of the mutant $\gamma 2 \mathrm{~S}(\mathrm{Q} 351 \mathrm{X})$ subunit, wild-type $\alpha 1$ subunits degraded more substantially within $1 \mathrm{~h}$ of translation. We showed that the basis for this dominant-negative effect on wild-type receptors was due to an interaction between mutant and wild-type subunits. The mutant subunit oligomerized with wild-type subunits and trapped them in the ER, subjecting them to glycosylation arrest and ER-associated degradation (ERAD) through the ubiquitin proteosome system. Thus, we hypothesize that a likely explanation for the GEFS + phenotype is a dominant-negative suppression of wild-type receptors by the mutant $\gamma 2 S$ subunit in combination with loss of mutant $\gamma 2 S$ subunit protein function.

\section{Introduction}

$\mathrm{GABA}_{\mathrm{A}}$ receptors are the major inhibitory neurotransmitter receptors in the CNS, and the $\alpha 1 \beta 2 \gamma 2 \mathrm{~S}$ receptor is the most abundant receptor isoform. The $\gamma 2$ subunit is critical for receptor trafficking, clustering and synaptic maintenance (Essrich et al., 1998; Schweizer et al., 2003), and several $\mathrm{GABA}_{\mathrm{A}}$ receptor $\gamma 2$ subunit missense mutations [ $\gamma 2(\mathrm{R} 43 \mathrm{Q})$ (Wallace et al., 2001), $\gamma 2(\mathrm{~K} 289 \mathrm{M})$ (Baulac et al., 2001), and $\gamma 2$ (R139G) (Audenaert et al., 2006)] and premature translation-termination codon (PTC)generating mutations $[\gamma 2(\mathrm{Q} 1 \mathrm{X})$ (Hirose, 2006), $\gamma 2(\mathrm{IVS6}+$ $2 \mathrm{~T} \rightarrow \mathrm{G})$ (Kananura et al., 2002), and $\gamma 2$ (Q351X) (Harkin et al., 2002)] have been associated with autosomal dominant idiopathic generalized epilepsies (IGEs). The missense mutations have been shown either to have reduced trafficking to the membrane surface with relatively normal function (Bianchi et al., 2002; Gallagher et al., 2004; Kang and Macdonald, 2004; Macdonald et al., 2006) or to traffic to the surface with impaired function (Feng et al., 2006, Bianchi et al., 2002). However, the pathophysiological mechanisms of $\mathrm{GABA}_{\mathrm{A}}$ receptor $\gamma 2$ subunit nonsense mutations are not clear.

\footnotetext{
Received 0ct. 3, 2008; revised Nov. 12, 2008; accepted Dec. 31, 2008.

This work was supported by a Citizens United for Research in Epilepsy research grant to J.-Q.K. and National Institutes of Health Grants R01 NS33300 and NS51590 to R.L.M. We give special thanks to Dr. Gregory Mathews for assistance with the mIPSC analysis.

Correspondence should be addressed to Dr. Jing-Qiong Kang, Vanderbilt University Medical Center, 6140 Medical Research Building III, 465 21st Avenue, South, Nashville, TN 37232-8552. E-mail: jingqiong.kang@vanderbilt.edu. DOI:10.1523/JNEUROSCI.4772-08.2009

Copyright $\odot 2009$ Society for Neuroscience $\quad$ 0270-6474/09/292845-12\$15.00/0
}

The $\gamma 2$ subunit nonsense mutation, Q351X, has been associated with generalized epilepsy with febrile seizures plus (GEFS+) (Harkin et al., 2002). Phenotypes in the affected pedigree ranged from simple febrile seizures to the more severe seizures of the Dravet syndrome. Mutant mRNAs containing PTCs are often degraded by nonsense-mediated mRNA decay (NMD) (Maquat, 2004). However, the PTC in $\gamma 2(\mathrm{Q} 351 \mathrm{X})$ subunits is located in the last exon of the GABRG2 gene. NMD only degrades mRNAs with PTCs at least 50-55 nt $5^{\prime}$ of an exon-exon junction, and therefore, does not degrade mRNAs with PTCs in the last exon (Holbrook et al., 2004). Thus, the $\gamma 2(\mathrm{Q} 351 \mathrm{X})$ subunit mRNA should not be subject to NMD. Recent studies also suggest that PTCs can activate mRNA degradation due to an improperly configured $3^{\prime}$-UTR, the "faux 3 '-UTR model," even if the PTC is located in the last exon (Amrani et al., 2004). However, studies on NMD in other diseases have shown that NMD is often incomplete (Kuzmiak and Maquat, 2006). Thus, it is likely that $\gamma 2$ (Q351X) subunit mRNA and truncated mutant protein are present in neurons of affected heterozygous patients.

In the present study, we demonstrated that $\gamma 2(\mathrm{Q} 351 \mathrm{X})$ subunit protein was produced but was immature and trafficking deficient, resulting in haploinsufficiency of the $\gamma 2$ subunit. In addition, it had a dominant-negative effect on wild-type receptors by reducing their assembly, trafficking and surface expression. The dominant-negative effect was likely due to oligomerization of mutant and wild-type subunits, resulting in ER retention and glycosylation arrest of both wild-type and mutant subunits. Retained, immature wild-type subunits were rapidly 
degraded by ERAD through the ubiquitinproteasomal system (UPS). As a result, the \%2 subunit mutation, Q351X, reduced mature surface $\mathrm{GABA}_{\mathrm{A}}$ receptors to an extent that was greater than that produced by hemizygous expression of the $\gamma 2$ subunit. This combination of loss of surface expression and function of the mutant subunits and the dominant-negative effect of the mutant subunits on the wild-type subunits would result in considerable loss of inhibition and is the likely explanation for the GEFS+ associated with this mutation.

\section{Materials and Methods}

Expression vectors with $G A B A_{A}$ receptor subunits. The cDNAs encoding human $\alpha 1, \beta 2, \gamma 2 S$, and enhanced cyan fluorescent protein (CFP)or yellow fluorescent protein (YFP)-tagged $\mathrm{GABA}_{\mathrm{A}}$ receptor subunits (e.g., $\gamma 2 \mathrm{~S}^{\mathrm{CFP}}, \alpha 1^{\mathrm{CFP}}$, or $\gamma 2 \mathrm{~S}^{\mathrm{YFP}}$ subunit) were as described previously (Kang and Macdonald, 2004; Kang et al., 2006). The $\gamma 2$ subunit minigenes were generated by inserting the full-length intron 8 of the $\gamma 2$ gene between exons 8 and 9 of the $\gamma 2$ subunit cDNA constructs. Since intron 8 contains the sequences for the $\gamma 2 \mathrm{~L}$ subunit, which is subject to alternative splicing inside the cells, the term $\gamma^{2}$ subunit minigene was used instead of either $\gamma 2 \mathrm{~L}$ or $\gamma 2 \mathrm{~S}$ subunit minigene in Figure 1. Similarly, we are not sure whether truncated wildtype or mutant $\gamma 2 \mathrm{~S}$ or $\gamma 2 \mathrm{~L}$ subunits were produced with expression of the intron 8 minigenes, and therefore, we refer to $\gamma 2$ and $\gamma 2(\mathrm{Q} 351 \mathrm{X})$ subunits when the subunits were a product of minigene expression. We used $\gamma 2 \mathrm{~S}$ or $\gamma 2 \mathrm{~L}$ subunit when referring to the cDNA constructs for the rest of study. The ecliptic pHluorin (a pH-sensitive GFP variant)-tagged rat $\gamma 2 \mathrm{~L}\left(\gamma 2 \mathrm{~L}^{\mathrm{pH}}\right)$ subunit was kindly provided by Dr. Stephen J. Moss (Tufts University School of Medicine, Boston, MA). The FLAG (DYKDDDDK) and HA (YPYDVPDYA) epitopes were inserted between amino acids 4 and 5 in the $\mathrm{N}$ terminus of the protein. Rat $\gamma 2$ subunit siRNA and primers were all synthesized by Qiagen. The anti- $\gamma 2$ subunit siRNA sequence (AAG AAA TCT GAT GAT GAC TAT) was complementary to an upstream sequence of the rat $\gamma 2$ subunit $\mathrm{N}$ terminus that was interrupted in the YFP-tagged human $\gamma 2 \mathrm{~S}^{\mathrm{YFP}}$ subunit sequence.

Cell culture. Hippocampi were dissected from the brains of embryonic day 18 Sprague Dawley rat pups. Dissociation of cells and cell culture and transfection procedures have been described previously (Kang et al., 2006).

Transfection. Transfection of HEK 293-T cells for electrophysiological experiments was as previously described (Kang and Macdonald, 2004). The total amounts of cDNAs transfected in different conditions were normalized by adding the empty vector pcDNA. Hippocampal neurons and HEK 293-T cells for immunoblots were transfected with Lipofectamine or Fugene (Invitrogen). Cells were cotransfected with $2 \mu \mathrm{g}$ of each subunit plasmid for each $60 \mathrm{~mm}^{2}$ dish and $1 \mu \mathrm{g}$ for each $35 \mathrm{~mm}^{2}$ dish. The siRNA was prepared according to the manufacturer's instructions (Qiagen), and siRNAs ( $5 \mu \mathrm{g})$ were transfected with Oligofectamine or Lipofectamine (Invitrogen) to cells in each $35 \mathrm{~mm}^{2}$ dish on the same day of the transfection of receptor subunits and on the third or fourth day after the transfection of receptor subunits to maintain suppression of the endogenous rat $\gamma 2$ subunit.

Electrophysiology. Lifted whole-cell recordings were obtained from transfected HEK 293-T cells as described previously (Kang and Macdonald, 2004). Cells were voltage clamped at $-50 \mathrm{mV}$, and $E_{\mathrm{Cl}}$ was $0 \mathrm{mV}$. For mIPSC recordings, hippocampal neurons were voltage clamped at $-60 \mathrm{mV}$, and tetrodotoxin (TTX) $(1 \mu \mathrm{M})$ was added to block action potentials. D-(-)-2-Amino-5-phosphonovaleric acid (AP5; $40 \mu \mathrm{M}$ ) and 6-cyano-7-nitroquinoxaline-2,3-dione (CNQX; $20 \mu \mathrm{M}$ ) were added to block NMDA and AMPA receptor-mediated excitatory synaptic currents, and 2-hydroxysaclofen $(100 \mu \mathrm{M})$ was added to block $\mathrm{GABA}_{\mathrm{B}}$ receptor currents. All chemicals were purchased from Sigma-Aldrich. The mIPSCs were abolished by addition of the $\mathrm{GABA}_{\mathrm{A}}$ receptor antagonist, bicuculline $(10 \mu \mathrm{M})$. Analysis of mIPSC frequencies and amplitudes were made using the Mini Analysis program by Justin Lee, which is available online.

Live-cell confocal microscopy and fluorescence quantification. Confocal microscopy and the measurements in COS-7 cells for each channel were performed as reported previously (Kang and Macdonald, 2004). Clusters in hippocampal neurons were counted by area (per $100 \mu \mathrm{m}$ ) as before (Kang et al., 2006). For labeling of rat $\gamma 2$ subunits, neurons were fixed with $4 \%$ paraformaldehyde $/ 0.2 \%$ picric acid $/ 0.05 \%$ glutaraldehyde for $1 \mathrm{~h}$ and then permeabilized with $0.2 \%$ Triton X-100 for $10 \mathrm{~min}$ before staining.

Biotinylation, immunoprecipitation, and Western blot analysis. Cell surface receptor biotinylation and Western blots were performed as re- 
ported previously (Kang and Macdonald, 2004). Membranes were incubated with primary mouse monoclonal antibodies against $\mathrm{GABA}_{\mathrm{A}}$ receptor $\alpha 1$ or $\beta 2 / 3$ subunits or GFP (Millipore Bioscience Research Reagents). Monoclonal HA antibody was purchased from Covance, and rabbit polyclonal anti- $\gamma_{2}$ subunit of GABA receptor antibody from Alamone Labs. After washing, membranes were incubated with horseradish peroxidase-conjugated secondary antibody [goat anti-mouse IgG (1:2000), goat anti-rabbit IgG (1:2000), Millipore Bioscience Research Reagents]. Digestion of protein lysates with Endo-H and PNGase F has been described previously (Gallagher et al., 2005). For immunoprecipitation, the wild-type $\gamma 2^{\mathrm{FLAG}}$ and $\gamma 2(\mathrm{Q} 351 \mathrm{X})^{\mathrm{FLAG}}$ subunits were purified by incubating cell lysates $(1 \mathrm{mg} / 1 \mathrm{ml})$ overnight with $50 \mu \mathrm{l}$ of agaroseimmobilized anti-FLAG M2 antibody (Sigma-Aldrich). The antibody resin was pelleted by centrifugation and washed three times with lysis buffer. FLAG-tagged subunits were liberated by incubation with FLAG peptide (Sigma-Aldrich) for $30 \mathrm{~min}$ on ice.

${ }^{35} \mathrm{~S}$ radiolabeling metabolic pulse-chase assays. The protocol was modified from our previous study (Gallagher et al., 2007). Briefly, $48 \mathrm{~h}$ after transfection, the cells were placed in starving medium that lacked methionine and cysteine (Invitrogen) and incubated at $37^{\circ} \mathrm{C}$ for $30 \mathrm{~min}$. The starving medium was then replaced by $1.5 \mathrm{ml}$ of $\left[{ }^{35} \mathrm{~S}\right]$ radionuclide methionine [ $100-250 \mu \mathrm{Ci} / \mathrm{ml}(1 \mathrm{Ci}=37 \mathrm{GBq})$; PerkinElmer] labeling medium for $20 \mathrm{~min}$ at $37^{\circ} \mathrm{C}$. The labeling medium was then changed to chase medium for a series of different time points. FLAG-tagged $\mathrm{GABA}_{\mathrm{A}}$ receptor subunits were then immunoprecipitated from radiolabeled lysates with anti-FLAG M2-agarose affinity gel by rotating at $4^{\circ} \mathrm{C}$ overnight. The immunoprecipitated products were eluted from the beads with FLAG peptide (Sigma-Aldrich). The immunopurified subunits were then analyzed by $12.5 \%$ SDS-PAGE and exposed on a digital PhosphorImager (GE Healthcare).

Data analysis. Macroscopic currents were low-pass filtered at $2 \mathrm{kHz}$, digitized at $10 \mathrm{kHz}$, and analyzed using the pClamp9 software suite (Molecular Devices). Numerical data were expressed as mean \pm SEM, except that the electrophysiology data for peak current amplitudes were plotted as mean $\pm \mathrm{SD}$. Proteins were quantified by ChemiImager AlphaEaseFC software, and data were normalized to either wild-type subunit proteins or loading controls. Pulse-chase experiments were quantified by using Quantity One software (Bio-Rad). Statistical significance, using Student's unpaired $t$ test (GraphPad Prism), was taken as $p<0.05$.

\section{Results}

The $\gamma 2$ subunit minigene was completely spliced, and $\gamma 2(\mathrm{Q} 351 \mathrm{X})$ subunit mRNA and protein were produced

The $\gamma 2$ subunit nonsense mutation, Q351X, is located in the TM3-TM4 loop, and the PTC should result in loss of the C-terminal 78 aa, thus producing a truncated subunit (Fig. 1A). The human $\gamma 2$ subunit gene, GABRG2, has 9 exons and 8 introns, and the mutation (red dot) is in the last exon (Fig. 1B). PTCs followed by an exon-exon junction $>50-55 \mathrm{nt}$ downstream generally activate NMD, but PTCs in the last exon should not activate NMD. To confirm that NMD was not activated by the $\gamma 2$ subunit Q351X mutation, we made wild-type and mutant subunit minigene constructs that contained intron 8 inserted between exons 8 and 9 (Fig. $1 B$ ) with and without a YFP epitope tag inserted into the $\mathrm{N}$ terminus of the mature peptide. We then expressed each minigene construct in HEK 293-T cells and used PCR with primer pairs in exon 7 and 8 that flanked the intron 8 insert (Fig. $1 B)$. We demonstrated that the intron 8 inserts in both the wildtype and mutant $\gamma 2$ subunit minigenes were correctly spliced out (Fig. 1C), suggesting that these minigenes were suitable for determining whether NMD was activated by the Q351X mutation.

We coexpressed YFP-tagged wild-type $\gamma 2^{\text {YFP }}$ or mutant $\gamma 2(\mathrm{Q} 351 \mathrm{X})^{\mathrm{YFP}}$ subunit minigenes with $\alpha 1$ and $\beta 2$ subunit $\mathrm{cD}$ NAs in HEK 293-T cells. Whole-cell lysates were analyzed by Western blot and blotted with anti-GFP antibody (Fig. 1D). In cells, transfected with the wild-type $\gamma 2^{\mathrm{YFP}}$ subunit minigene,

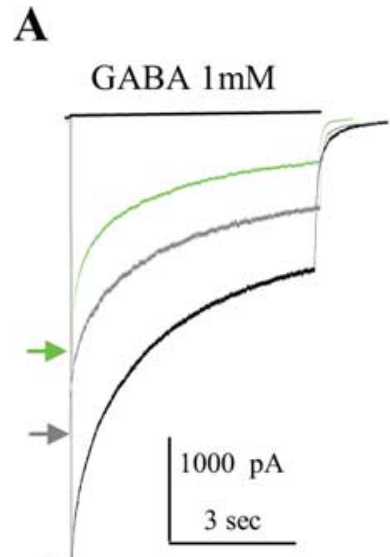

B

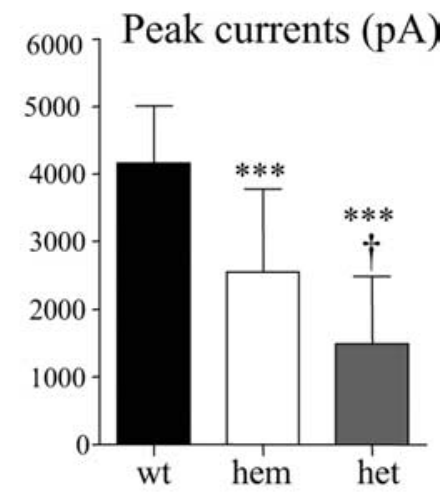

Black trace: $\alpha 1 \beta 2 \gamma 2 \mathrm{~S}(\mathrm{wt})$

Gray trace: $\alpha 1 \beta 2 \gamma 2 \mathrm{~S} /-($ hem)

Green trace: $\alpha 1 \beta 2 \gamma 2 \mathrm{~S} / \gamma 2 \mathrm{~S}(\mathrm{Q} 351 \mathrm{X})$ (het)

Figure 2. Expression of heterozygous $\gamma 2 S / \gamma 2 S(0351 X)$ subunits and $\alpha 1$ and $\beta 2$ subunits resulted in reduced peak current amplitudes compared with expression of wild-type or hemizygous control $\alpha 1, \beta 2$, and $\gamma 25$ subunits. $A, \mathrm{GABA}_{\mathrm{A}}$ receptor currents were obtained from HEK 293-T cells cotransfected with wild-type $\alpha 1$ and $\beta 2$ subunits and $\gamma 2 S$ (1:1:1 cDNA ratio; wt, black trace), hemizygous control $\gamma 2 S$ (1:1:0.5 (DNA ratio; hem, gray trace), or heterozygous $\gamma 2 S / \gamma 2 S(0351 X)$ (1:1:0.5:0.5 CDNA ratio; het, green trace) subunits with application of $1 \mathrm{~mm}$ GABA applied for $6 \mathrm{~s}$. Peak wt, hem, and het currents were marked with a black arrow, a gray arrow or a green arrow, respectively. $\boldsymbol{B}$, The amplitudes of $G A B A_{A}$ receptor currents from $A$ were plotted. Values were mean \pm SD ( $n=15-16$ cells from 6 different transfections) ${ }^{* * *} p<$ 0.001 vs wt, ${ }^{\dagger} p<0.05$ vs hem).

there was a prominent band at $\sim 68 \mathrm{kDa}$ (Fig. $1 D$, wt). In cells cotransfected with the homozygous $\gamma 2(\mathrm{Q} 351 \mathrm{X})^{\mathrm{YFP}}$ subunit minigene, a main band at $\sim 58 \mathrm{kDa}$ was detected, consistent with the expected shift in molecular mass produced by a truncated subunit (Fig. $1 D$, hom). With expression of heterozygous $\gamma 2^{\mathrm{YFP}} /$ $\gamma 2(\mathrm{Q} 351 \mathrm{X})^{\mathrm{YFP}}$ subunit minigenes, two bands were detected. Surprisingly, the band with the molecular mass of the wild-type subunit was faint, and the band with the molecular mass of the mutant subunit was strong (Fig. $1 \mathrm{D}$, het).

\section{Heterozygous $\alpha 1 \beta 2 \gamma 2 S / \gamma 2 S(Q 351 X)$ receptor currents were} reduced compared with wild-type $\alpha 1 \beta 2 \gamma 2 S$ or hemizygous control $\alpha 1 \beta 2 \gamma 2 S(+/-)$ receptor currents

Based on our minigene results, truncated mutant $\gamma 2$ subunits were produced. To determine the effect of the truncated $\gamma 2 \mathrm{~S}(\mathrm{Q} 351 \mathrm{X})$ subunit on expression of functional $\mathrm{GABA}_{\mathrm{A}}$ receptors, we used wild-type and mutant $\gamma 2 \mathrm{~S}$ subunit cDNA constructs. We recorded from HEK 293-T cells following cotransfection of $\alpha 1$ and $\beta 2$ subunits with wild-type $\gamma 2 S$ subunits (1:1:1 cDNA ratio), a 50\% concentration of hemizygous $\gamma 2 S$ subunit (1:1:0.5 cDNA ratio) or heterozygous $\gamma 2 \mathrm{~S} / \gamma 2 \mathrm{~S}(\mathrm{Q} 351 \mathrm{X})$ subunits (1:1:0.5:0.5 cDNA ratio). We used "wild-type," "hemizygous," "heterozygous," and "homozygous" subunit expression, receptors, and currents to indicate that we transfected cells with nonmutant (wild-type) cDNAs, half concentrations of nonmutant cDNAs (hemizygous), an equal mixture of nonmutant and mutant cDNAs (heterozygous), or mutant cDNAs (homozygous) and studied their expression and function. We used this notation to facilitate descriptions of the transfection techniques, and no genetic mechanism or specific assembly patterns were implied.

Currents were evoked by application of $1 \mathrm{~mm}$ GABA for $6 \mathrm{~s}$ (Fig. 2A) or $28 \mathrm{~s}$ (data not shown). Hemizygous control receptor peak currents $(2551 \pm 1268 \mathrm{pA})(n=16)$ were reduced to $61.3 \%$ 
of wild-type receptor currents (4161 \pm $852 \mathrm{pA})(n=17 ; p<0.001)$ (Fig. $2 A, B)$. Heterozygous receptor peak currents $(1449 \pm 955 \mathrm{pA})(n=15)$ were reduced to $34.9 \%$ of wild-type receptor currents $(p<$ $0.0001)$ and to $56.9 \%$ of hemizygous control receptor currents $(p=0.012$ ) (Fig. $2 A, B)$. Only very small currents were occasionally recorded from cells cotransfected with $\alpha 1$ and $\beta 2$ subunits and "homozygous" $\gamma 2 \mathrm{~S}(\mathrm{Q} 351 \mathrm{X})$ subunits (1:1:1 cDNA ratio) (data not shown).

With coexpression of heterozygous $\gamma 2 \mathrm{~S} /$ $\gamma 2 \mathrm{~S}(\mathrm{Q} 351 \mathrm{X})$ subunits and $\alpha 1$ and $\beta 2$ subunits, surface expression of wildtype $\gamma 2 S$ subunits was reduced due to ER retention

The current amplitude recorded with expression of heterozygous $\alpha 1 \beta 2 \gamma 2 \mathrm{~S}$ receptors was less than half that recorded from wild-type receptors and was less than that recorded from hemizygous control receptors. Was the reduced current recorded with expression of heterozygous $\alpha 1 \beta 2 \gamma 2 \mathrm{~S}$ receptors a result of loss of surface receptors due to the failure of assembly of $\gamma 2 \mathrm{~S}(\mathrm{Q} 351 \mathrm{X})$ subunits and/or due to reduction of surface $\alpha 1 \beta 2 \gamma 2 \mathrm{~S}$ receptors? To explore this question, we characterized the trafficking pattern of receptors with heterozygous expression of $\gamma 2 \mathrm{~S} / \gamma 2 \mathrm{~S}(\mathrm{Q} 351 \mathrm{X})$ subunits as would be seen in an autosomal dominant disease. We determined the surface expression of $\gamma 2 S$ subunits by biotinylation and immunoblotting following cotransfection of HEK 293-T cells with $\alpha 1$ and $\beta 2$ subunits and wild-type $\gamma 2 \mathrm{~S}^{\mathrm{YFP}}$, hemizygous control $\gamma 2 S^{\mathrm{YFP}}$, heterozygous $\gamma 2 \mathrm{~S}^{\mathrm{YFP}} / \gamma 2 \mathrm{~S}(\mathrm{Q} 351 \mathrm{X})^{\mathrm{YFP}}$, and homozygous $\gamma 2 \mathrm{~S}(\mathrm{Q} 351 \mathrm{X})^{\mathrm{YFP}}$ subunits (Fig. 3A, left). For all expression conditions, surface $\gamma 2 \mathrm{~S}^{\mathrm{YFP}} / \gamma 2 \mathrm{~S}(\mathrm{Q} 351 \mathrm{X})^{\mathrm{YFP}}$ subunit protein IDVs were normalized to wild-type levels (Fig. 3A, right). Hemizygous control $\gamma 2 S^{\mathrm{YFP}}$ subunit surface levels were reduced relative to control wild-type $\gamma 2 \mathrm{~S}^{\mathrm{YFP}}$ subunit levels $(0.68 \pm 0.03, n=7, p<0.001)$. Heterozygous $\quad \gamma 2 S^{\mathrm{YFP}} / \gamma 2 \mathrm{~S}(\mathrm{Q} 351 \mathrm{X})^{\mathrm{YFP}}$ subunit surface levels were also reduced relative to control wild-type $\gamma 2 \mathrm{~S}^{\mathrm{YFP}}$ subunit levels $(0.43 \pm 0.04, n=7, p<0.0001)$ and were also reduced relative to the hemizygous control condition ( $p=0.0002)$. Homozygous $\gamma 2 \mathrm{~S}(\mathrm{Q} 351 \mathrm{X})^{\mathrm{YFP}}$ subunit expression was reduced to such an extent that no significant surface protein was detected.

Because the mutant subunit did not appear to traffic to the cell surface, we determined the subcellular location of the mutant protein by cotransfecting COS-7 or HEK 293-T (data not shown) cells with $\gamma 2 S^{\text {YFP }}$ and/or $\gamma 2 S(Q 351 X)^{\text {YFP }}$ subunits and $\alpha 1$ and $\beta 2$ subunits. The surface membrane was

A

B

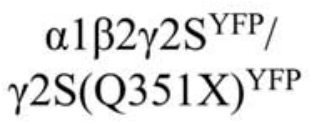

wt hem het hom

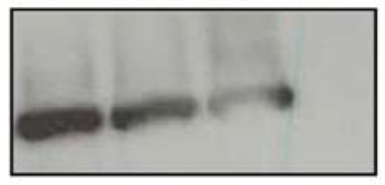

anti-GFP

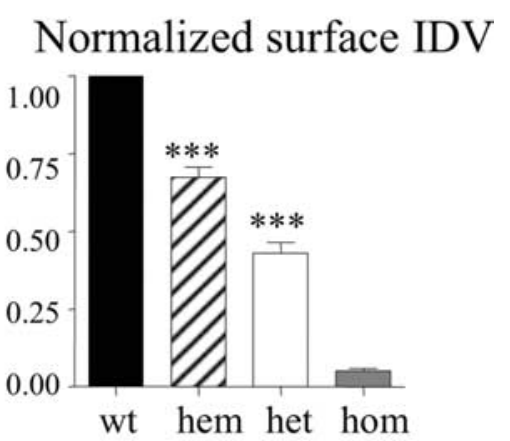

wt hem het hom

HEK 293-T cells
$\alpha 1 \beta 2 \gamma 2 \mathrm{~S}^{\mathrm{YFP}} / \gamma 2 \mathrm{~S}(\mathrm{Q} 351 \mathrm{X})^{\mathrm{YFP}}$
wt het hom
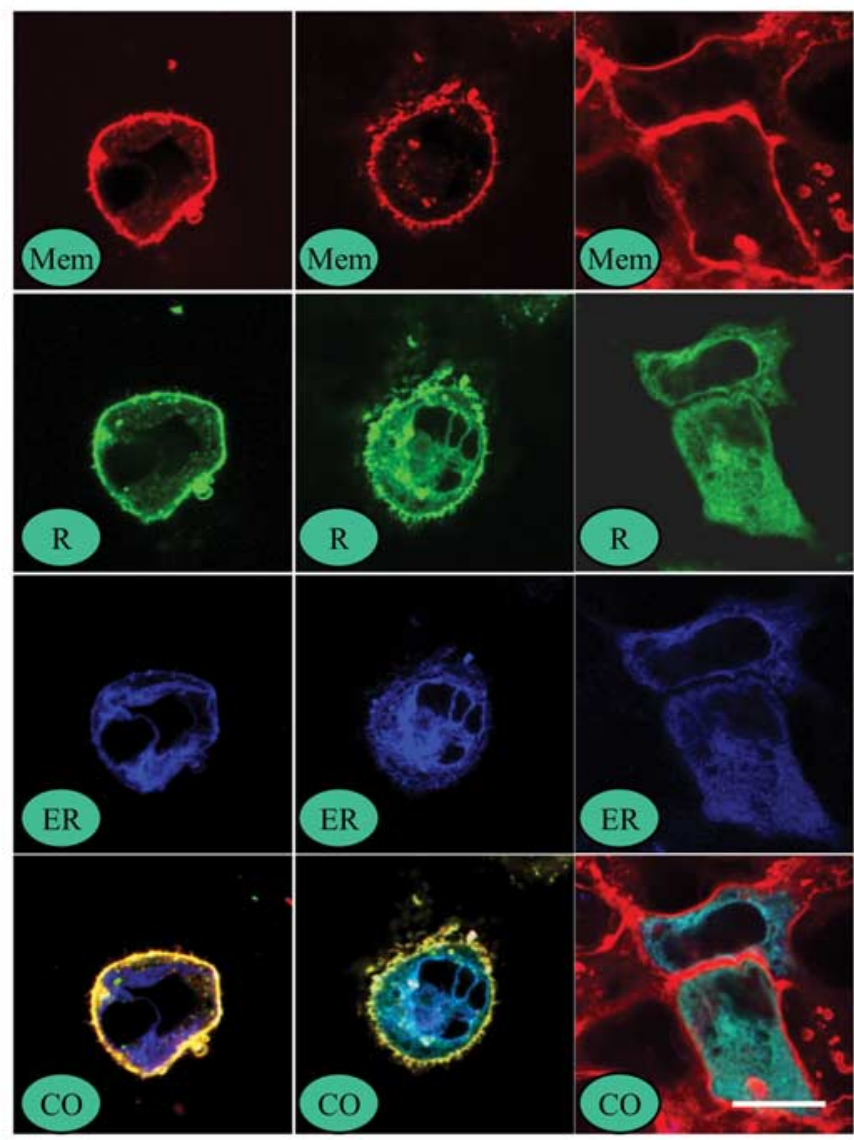

COS-7 cells

Bar: $15 \mu \mathrm{m}$

Figure 3. With heterozygous expression, surface $\gamma 2 S$ subunit levels were reduced and $\gamma 2 S$ subunits were retained in the ER. $A$, HEK 293-T cells were cotransfected with $\alpha 1$ and $\beta 2$ subunits and $\gamma 2 S^{\text {YFP }}$ (1:1:1 CDNA ratio, wt), $\gamma 22^{\text {YFP }}$ (1:1:0.5 CDNA ratio, hem), $\gamma 2 S^{\mathrm{YFP}} / \gamma 2 \mathrm{~S}(\mathrm{Q} 351 \mathrm{X})^{\mathrm{YFP}}$ (1:1:0.5:0.5 CDNA ratio, het), or $\gamma 2 \mathrm{~S}(\mathrm{Q} 351 \mathrm{X})^{\mathrm{YFP}}$ (1:1:1 CDNA ratio, hom) subunits, and surface proteins were biotinylated, isolated, separated by SDS-PAGE, and probed with anti-GFP antibody. Surface proteins were normalized to the wild-type $\gamma 2 S^{\text {YFP }}$ subunit protein. Values are mean \pm SEM $(n=7)\left({ }^{* * *} p<0.001 \mathrm{vs}\right.$ wt). $B, C O S-7$ cells were cotransfected with $\alpha 1$ and $\beta 2$ subunits and $\gamma 2 S^{\mathrm{YFP}}$ (1:1:1 CDNA ratio, wt), $\gamma 2 S^{\mathrm{YFP}} / \gamma 2 \mathrm{~S}(\mathrm{Q} 351 \mathrm{X}){ }^{\mathrm{YFP}}$ (1:1:0.5:0.5 CDNA ratio, het), or $\gamma 2 \mathrm{~S}(\mathrm{Q} 351 \mathrm{X})^{\mathrm{YFP}}$ (1:1:1 CDNA ratio, hom) subunits, and the images were obtained $48 \mathrm{~h}$ later under confocal microscopy. Mem stands for membrane, $R$ for $\gamma 2 S^{\mathrm{YFP}}$ subunit, ER for endoplasmic reticulum, and $C O$ for colocalized images.

identified using the plasma membrane marker FM4-64 (red) (Fig. $3 B, \mathrm{Mem}$ ), and the ER was marked by pECFP-ER (blue) (Fig. 3B, ER). The surface and intracellular distributions of wildtype $\gamma 2 S^{\mathrm{YFP}}$ and $\gamma 2 \mathrm{~S}(\mathrm{Q} 351 \mathrm{X})^{\mathrm{YFP}}$ subunits (green) were deter- 


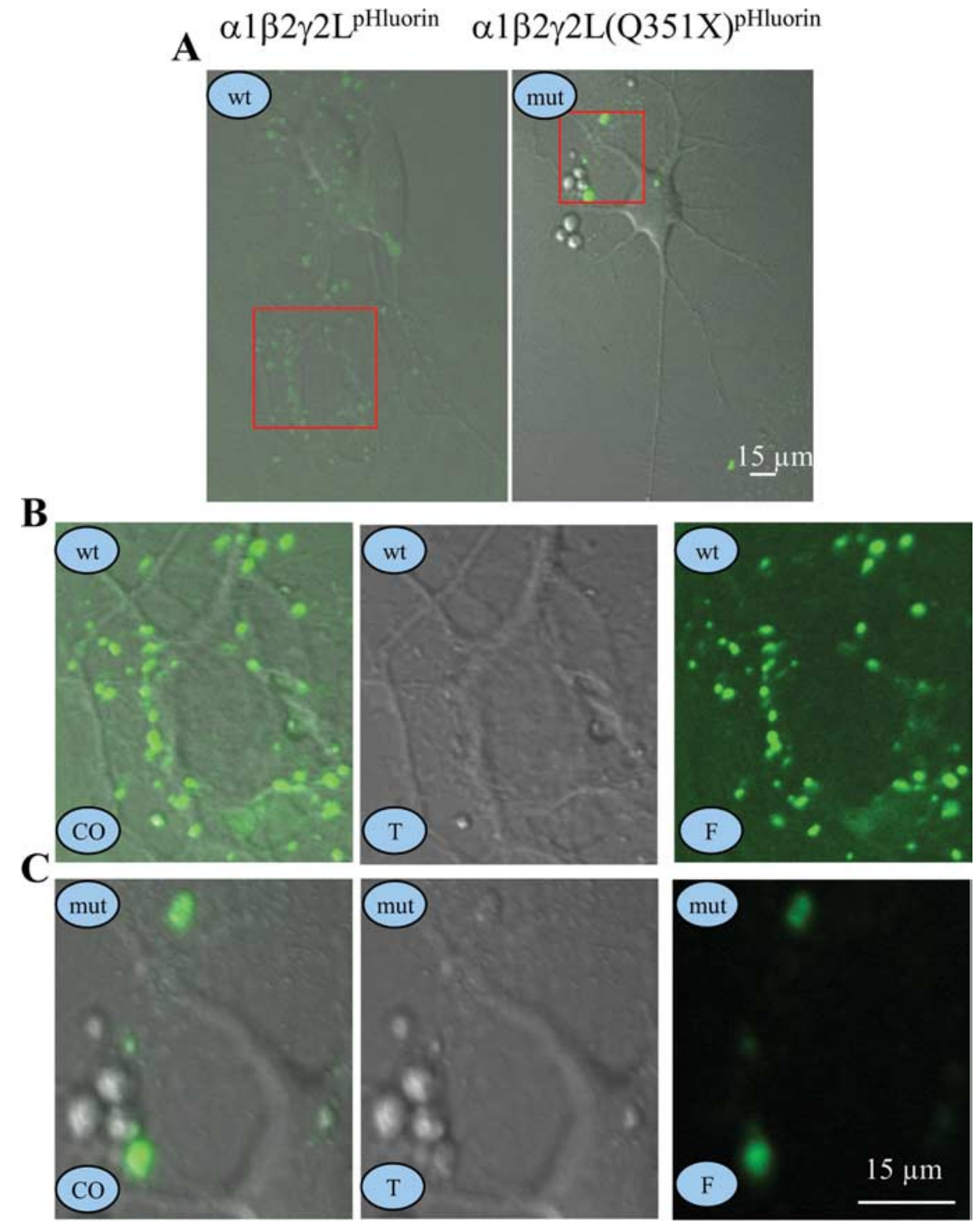

Figure 4. $\quad \gamma 2 \mathrm{~L}(\mathrm{Q} 351 \mathrm{X})^{\mathrm{pHluorin}}$ subunit protein had minimal expression on the surface of rat hippocampal neurons. $\boldsymbol{A}-\boldsymbol{C}$, Rat hippocampal neurons were transfected with $\alpha 1 \beta 2 \gamma 2 \mathrm{~L}^{\text {pHluorin }}$ (wt) or $\alpha 1 \beta 2 \gamma 2 \mathrm{~L}(\mathrm{Q} 351 \mathrm{X})^{\text {pHlluorin }}$ (mut) subunits for $6 \mathrm{~d}$ and were imaged as puncta on the surface of neurons. $\boldsymbol{A}$, Representative images of wt $\gamma 2 \mathrm{~L}^{\mathrm{pHluorin}}$ or mut $\gamma 2 \mathrm{~L}(\mathrm{Q} 351 \mathrm{X})^{\mathrm{pHluorin}}$ subunits are presented. $\boldsymbol{B}, \boldsymbol{C}$, Enlarged views of the boxed areas for wt $(\boldsymbol{B})$ and mut $(\boldsymbol{C})$ receptors in $\boldsymbol{A}$. In $\boldsymbol{A}-\boldsymbol{C}$, wt stands for wild-type $\gamma 2 \mathrm{~L}^{\mathrm{pHluorin}}$ subunits, mut stands for mutant $\gamma \mathrm{LL}(\mathrm{Q} 351 \mathrm{X})^{\text {pHluorin }}$ subunits, $\mathrm{C} 0$ stands for colocalized images, T stands for transmitted images, and F stands for fluorescent images.

mined (Fig. 3B, R). All three signals were coregistered to demonstrate their relative subcellular localizations (Fig. $3 B, \mathrm{CO}$ ). Wildtype $\gamma 2 S^{\mathrm{YFP}}$ subunit fluorescence was primarily on the surface and had a smooth distribution (Fig. 3B, wt, CO). Heterozygous expression resulted in reduced surface expression and increased intracellular expression of $\gamma 2 S^{\mathrm{YFP}} / \gamma 2 \mathrm{~S}\left(\mathrm{Q} 351 \mathrm{X}\right.$ ) ${ }^{\mathrm{YFP}}$ subunits (Fig. $3 B$, het, $\mathrm{CO}$ ). Homozygous expression resulted in no visible surface expression with substantial intracellular ER localization of $\gamma 2 \mathrm{~S}(\mathrm{Q} 351 \mathrm{X})^{\mathrm{YFP}}$ subunits (Fig. 3B, hom, CO).

\section{When coexpressed with $\alpha 1$ and $\beta 2$ subunits, $\gamma 2 \mathrm{~L}(\mathrm{Q} 351 \mathrm{X})$} pHluorin-tagged subunits had minimal expression on the surface of rat hippocampal neurons

Because the data above were obtained using HEK 293-T and COS-7 cells, we extended the study to determine the surface expression of wild-type and mutant subunits in neurons. pHluorintagged rat $\gamma 2 \mathrm{~L}^{\mathrm{pH}}$ and $\gamma 2 \mathrm{~L}(\mathrm{Q} 351 \mathrm{X})^{\mathrm{pH}}$ subunits were coexpressed with human $\alpha 1$ and $\beta 2$ subunits in hippocampal neurons for $6 \mathrm{~d}$. We used $\gamma 2 \mathrm{~L}$ instead of $\gamma 2 \mathrm{~S}$ subunits since $\gamma 2 \mathrm{~L}$ subunits cannot traffic to the surface alone but $\gamma 2 \mathrm{~S}$ subunits can. pHluorin should only generate fluorescence when at the cell surface and should produce minimal fluorescence at the acidic $\mathrm{pHs}(\mathrm{pH}<6.5)$ that are characteristic of vesicular compartments (Miesenböck et al., 1998). After 6 d, fluorescence from $\gamma 2 \mathrm{~L}^{\mathrm{pH}}$ and $\gamma 2 \mathrm{~L}(\mathrm{Q} 351 \mathrm{X})^{\mathrm{pH}}$ subunits was visible and appeared as puncta on neurons (Fig. $4 A$; enlarged views for the red boxed areas in Fig. $4 A$ are shown in Fig. $4 B, C$ ). Because pHluorin only fluoresces at the surface and $\gamma 2 \mathrm{~L}$ subunits cannot traffic to the surface alone but can with $\beta 2$ or $\alpha 1$ subunits, the puncta on neurons were assumed to be surface $\gamma 2 \mathrm{~L}$ subunits assembled in receptors. Neurons cotransfected with wild-type $\alpha 1 \beta 2 \gamma 2 \mathrm{~L}^{\mathrm{pH}}$ subunits (Fig. $4 A$, wt, $B$ ) had many more fluorescent puncta than neurons cotransfected with $\alpha 1 \beta 2 \gamma 2 \mathrm{~L}(\mathrm{Q} 351 \mathrm{X})$-pHluorin subunits (Fig. $4 A$, mut, $C$ ), indicating that the majority of mutant receptors were trapped intracellularly in neurons.

\section{With coexpression of heterozygous} $\gamma 2 \mathrm{~S}^{\mathrm{YFP}} / \gamma 2 \mathrm{~S}(\mathrm{Q} 351 \mathrm{X})^{\mathrm{YFP}}$ subunits and $\alpha 1$ and $\beta 2$ subunits in hippocampal neurons, mIPSCs had reduced peak current and reduced number of events It is also important to characterize the functional properties of mutant heterozygous currents in neurons. However, since there were endogenous $\gamma 2$ subunitcontaining receptors in neurons, it would be difficult to characterize the phenotype of heterozygous receptors. We thus designed an siRNA to "knock down" endogenous $\gamma 2$ subunits. Rat hippocampal neurons treated for 6-8 d with siRNA $(5 \mu \mathrm{g})$ targeting the rat $\gamma 2$ subunit gene had significantly reduced $\gamma 2$ subunit protein fluorescence compared with the untreated control cultures as probed with anti-rat $\gamma 2$ antibody and visualized with FITC (Fig. $5 A$ ) or by measuring the $\gamma 2$ subunit total protein (Fig. $5 B$ ).

GABA ( $1 \mathrm{~mm})$ evoked large currents $(6003 \pm 598 \mathrm{pA}, n=14)$ from untreated hippocampal neurons but evoked only small currents from siRNA-treated neurons $(59.6 \pm 11.7 \mathrm{pA}, n=9)$ (Fig. $5 E)$. Diazepam $(1 \mu \mathrm{M})$ enhanced GABA $(2 \mu \mathrm{M})$-evoked currents in neurons untreated with siRNA $(217 \% \pm 15.3 \%, n=5)$, but not in neurons treated with siRNA $(110.6 \pm 10.3 \%, n=5)$ (Fig. $5 C)$, consistent with reduction of $\gamma 2$ subunit-containing $\mathrm{GABA}_{\mathrm{A}}$ receptors in siRNA-treated neurons. Wild-type $\gamma 2 S^{\mathrm{YFP}}$, heterozygous $\gamma 2 \mathrm{~S}^{\mathrm{YFP}}$ / $\gamma 2 \mathrm{~S}(\mathrm{Q} 351 \mathrm{X})^{\mathrm{YFP}}$, and homozygous $\gamma 2 \mathrm{~S}(\mathrm{Q} 351 \mathrm{X})^{\mathrm{YFP}}$ subunit cDNAs and $\alpha 1$ and $\beta 2$ cDNAs were then cotransfected into hippocampal neurons in addition to treatment with siRNA (5 $\mu \mathrm{g})$ for 6-8 d. Neurons were voltage clamped at $-50 \mathrm{mV}$, and GABA (1 mM) was applied for $28 \mathrm{~s}$. GABA evoked large and rapidly desensitizing currents from wild-type receptors $(1789.5 \pm 234.1 \mathrm{pA}, n=11)$ and 

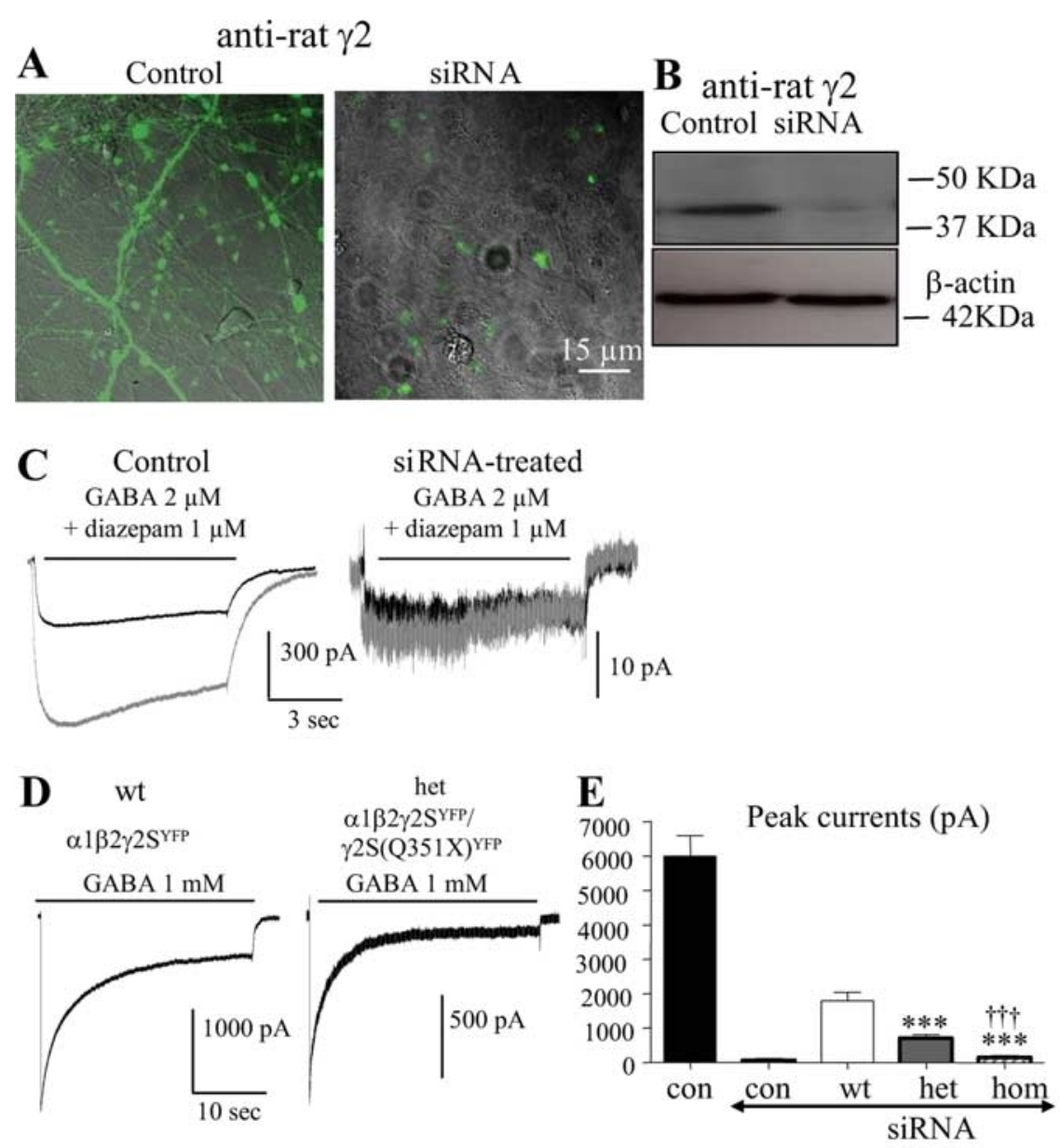

F

wt
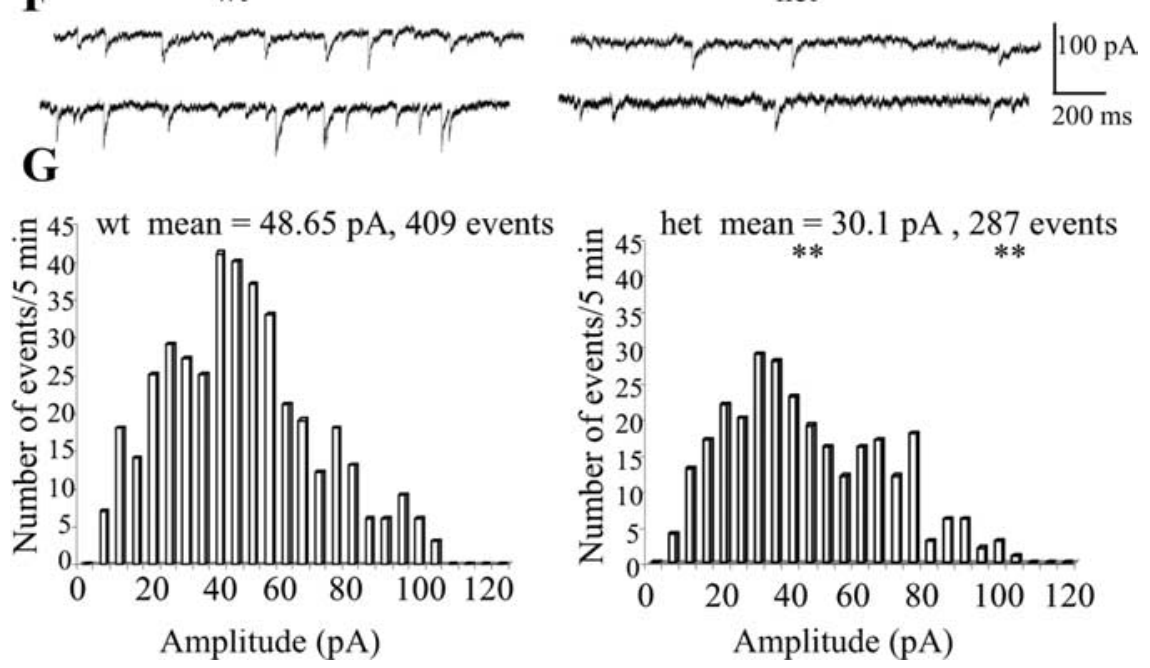

Figure 5. Heterozygous $\alpha 1 \beta 2 \gamma 2 \mathrm{~S}(\mathrm{Q} 351 \mathrm{X})$ receptor current amplitudes were less than half of wild-type peak current amplitudes in hippocampal neurons. $\boldsymbol{A}$, Rat hippocampal neurons in the absence or presence of $5 \mu \mathrm{g}$ of siRNA targeting the rat $\gamma 2$ subunit gene for $8 \mathrm{~d}$ were permeabilized and stained with anti-rat $\gamma 2$ antibody and visualized with FITC. $\boldsymbol{B}$, The whole-cell lysates from the sister dishes were probed with rabbit anti-rat $\gamma 2$ antibody by Western blot. $\boldsymbol{C}$, Whole-cell currents evoked by GABA ( 2 $\mu \mathrm{m})$ and GABA (2 $\mu \mathrm{m})$ plus diazepam (1 $\mu \mathrm{m})$ were recorded from 16-d-old hippocampal neurons in the absence (Control) or presence of $5 \mu \mathrm{g}$ of siRNA targeting the rat $\gamma 2$ subunit gene for $6-8 \mathrm{~d}$ (siRNA). D, Wild-type $\alpha 1 \beta 2 \gamma 2 S^{\mathrm{YFP}}$, heterozygous $\alpha 1 \beta 2 \gamma 2 S^{\mathrm{YFP}} / \gamma 2 \mathrm{~S}(\mathrm{Q} 351 \mathrm{X})^{\mathrm{YFP}}$, and homozygous $\left.\alpha 1 \beta 2 \gamma 2 \mathrm{~S}(\mathrm{Q} 351 \mathrm{X})\right)^{\mathrm{YFP}}$ receptor currents from 15- to 16-d-old endogenous $\gamma 2$ subunit silenced hippocampal neurons were evoked with GABA (1 mm) for $28 \mathrm{~s}$. $\boldsymbol{E}$, The peak current amplitudes of neurons untreated (con) or treated with siRNA (siRNA) and transfected with human $\alpha 1 \beta 2 \gamma 2 S^{\mathrm{YFP}}$ (wt), $\alpha 1 \beta 2 \gamma 2 S^{\mathrm{YFP}} / \gamma 2 \mathrm{~S}$ (Q351X) ${ }^{\mathrm{YFP}}$ (het), and $\alpha 1 \beta 2 \gamma 2 S(0351 X)^{\mathrm{YFP}}$ (hom) were plotted $\left(^{* * *} p<0.001\right.$ vs wt, ${ }^{\text {t+t }}$ hom vs het, data from 13-15 cells from 5 batches of cells). $\boldsymbol{F}, \mathbf{G}$, GABAergic mIPSCs for cells transfected with $\alpha 1$ and $\beta 2$ subunits and wild-type $\gamma 2 S^{\text {YFP }}$ or heterozygous $\gamma 2 S^{\text {YFP }}$ / $\gamma 2 S(Q 351 X)^{Y F P}$ subunits were recorded at a holding potential of $-60 \mathrm{mV}$. G, Individual mIPSCs from a 5 min recording period were averaged for wild-type and heterozygous subunit-transfected cells. The amplitude distributions of mIPSCs obtained smaller currents from heterozygous receptors (Fig. $5 D, E)(695 \pm 67.9 \mathrm{pA}, n=12)$ $(p<0.0001$ vs wt). Only minimal currents were obtained from homozygous receptors $(140 \pm 21.2 \mathrm{pA}, n=7)(p<0.0001 \mathrm{vs}$ wt or het) (Fig. 5E). The heterozygous current was less than half of the wild-type current, suggesting a dominant-negative effect of the mutant protein on the wild-type receptors in neurons.

We also recorded mIPSCs from the same groups of neurons. The cells were voltage clamped at $-60 \mathrm{mV}$, and mIPSCs were recorded from neurons transfected with wild-type $\alpha 1 \beta 2 \gamma 2 \mathrm{~S}^{\mathrm{YFP}}$ and heterozygous $\alpha 1 \beta 2 \gamma 2 \mathrm{~S}^{\mathrm{YFP}} / \gamma 2 \mathrm{~S}(\mathrm{Q} 351 \mathrm{X})^{\mathrm{YFP}}$ receptors (Fig. $5 F$ ). The mIPSCs from neurons transfected with heterozygous receptors had a significantly smaller mean peak amplitude (30.1 vs $48.65 \mathrm{pA}$ ) and fewer events (287 vs 409 events) than mIPSCs from neurons transfected with wild-type receptors (Fig. 5G).

With heterozygous expression, mutant $\gamma 2 S(Q 351 X)$ subunits had immature glycosylation, and wild-type $\gamma 2 S$ subunits had less total and less mature glycosylation compared with hemizygous expression of $\boldsymbol{\gamma} 2 \mathrm{~S}$ subunits To explore the basis for the reduction of surface wild-type $\gamma 2 \mathrm{~S}$ subunit proteins with coexpression of heterozygous $\gamma 2 \mathrm{~S} /$ $\gamma 2 \mathrm{~S}(\mathrm{Q} 351 \mathrm{X})$ subunits and $\alpha 1$ and $\beta 2$ subunits in HEK 293-T cells (Fig. 3), we determined the total expression and maturity of wild-type and mutant $\gamma 2 \mathrm{~S}$ subunit proteins following coexpression of $\alpha 1$ and $\beta 2$ subunits and wild-type $\gamma 2 S^{\mathrm{YFP}}$, heterozygous $\gamma 2 S^{\mathrm{YFP}} / \gamma 2 \mathrm{~S}(\mathrm{Q} 351 \mathrm{X})^{\mathrm{YFP}}$, or homozygous $\gamma 2 \mathrm{~S}(\mathrm{Q} 351 \mathrm{X})^{\mathrm{YFP}}$ subunits (Fig. 6). As observed in previous studies, $\gamma 2$ subunit protein bands in Western blots were often smeared rather than discreet (Connolly et al., 1996). With expression of wild-type subunits, the $\gamma 2 \mathrm{~S}^{\mathrm{YFP}}$ subunit protein usually migrated as a single, broad main band at $\sim 68 \mathrm{kDa}$, and with homozygous subunit expression, the $\gamma 2 \mathrm{~S}(\mathrm{Q} 351 \mathrm{X})^{\mathrm{YFP}}$ subunit protein migrated as a main band at $\sim 58$ $\mathrm{kDa}$, consistent with the reduced molecular mass of the truncated subunit, and sometimes as a faint band $\sim 45 \mathrm{kDa}$, which was likely to be unglycosylated $\gamma 2 \mathrm{~S}(\mathrm{Q} 351 \mathrm{X})^{\mathrm{YFP}}$ subunit protein (Fig. 6A). With heterozygous $\gamma 2 S^{\mathrm{YFP}} / \gamma 2 \mathrm{~S}(\mathrm{Q} 351 \mathrm{X})^{\mathrm{YFP}}$ subunit ex-

\section{$\leftarrow$}

during a 5 min recording period were displayed in a histogram. The histograms were fitted using Mini Analysis program by Justin Lee ${ }^{* *} p<0.01$ het vs wt, $n=6$ for each group). 

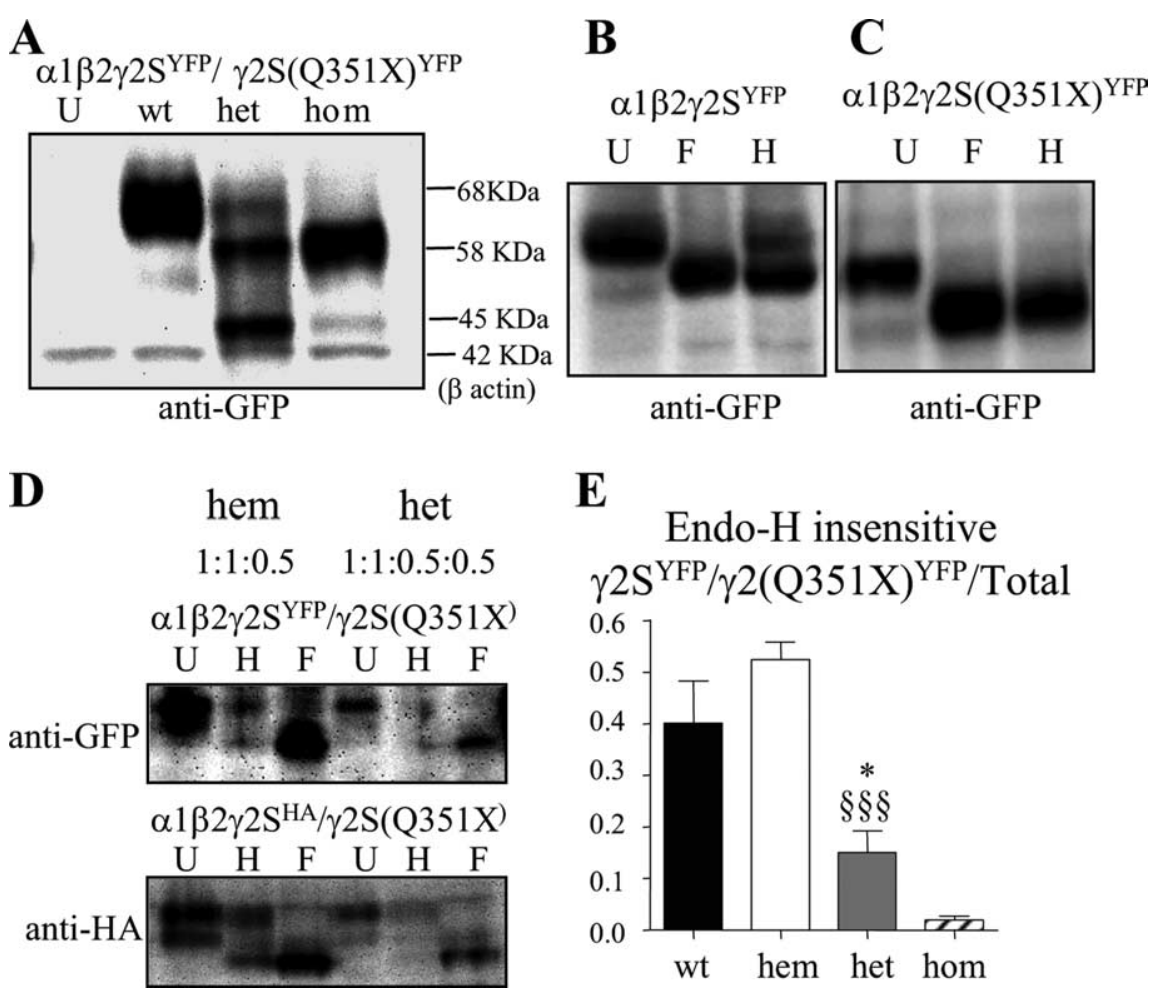

Figure 6. Glycosylation arrest caused the reduction of mature wild-type $\gamma 2 S$ subunit protein. $A$, HEK 293-T cells were cotransfected with $\alpha 1$ and $\beta 2$ subunits and wild-type $\gamma 2 S^{\mathrm{YFP}}$ (1:1:1 cDNA ratio, wt), heterozygous $\gamma 2 S^{\mathrm{YFP}} / \gamma 2 \mathrm{~S}(\mathrm{Q} 351 \mathrm{X})^{\mathrm{YFP}}$ (1:1:0.5:0.5 CDNA ratio, het), or homozygous $\gamma 2 S(Q 351 X)^{Y F P}(1: 1: 1$ cDNA ratio, hom) subunits. Total proteins were analyzed by SDS-PAGE and probed with anti-GFP antibody. B, C, The total cell lysates with wild-type $\gamma 2 S^{\mathrm{YFP}}(\boldsymbol{B})$ or mutant $\gamma 2 \mathrm{~S}(\mathrm{Q} 351 \mathrm{X})^{\mathrm{YFP}}(\boldsymbol{C})$ subunit transfection were undigested $(\mathrm{U})$ or digested with PNGase $\mathrm{F}(\mathrm{F})$ or Endo-H $(\mathrm{H})$. D, Total cell lysates of hemizygous control $\alpha 1 \beta 2 \gamma 2 S^{\mathrm{YFP}} / \mathrm{pcDNA}$ or $\alpha 1 \beta 2 \gamma 2 \mathrm{~S}^{\mathrm{HA} / p C D N A}$ (1:1:0.5:0.5 CDNA ratio) subunits and heterozygous $\alpha 1 \beta 2 \gamma 25^{\mathrm{YFP}} / \gamma 2 \mathrm{~S}(\mathrm{Q} 351 \mathrm{X})$ or $\alpha 1 \beta 2 \gamma 2 S^{\mathrm{HA}} / \gamma 2 \mathrm{~S}(\mathrm{Q} 351 \mathrm{X})$ subunits (1:1:0.5:0.5 CDNA ratio) were transfected into HEK 293-T cells and undigested (U) or digested with Endo-H (H) or PNGase $F(F)$. $E$, The protein bands insensitive to Endo-H were quantified and presented as a fraction of their total undigested bands ( ${ }^{*} p<0.05$ vs wt; ${ }^{\circledR \S \S} p<0.001$ vs hem; $n=5$ ). Values are mean \pm SEM.

pression, subunit proteins migrated in two or three bands with a minor band at $\sim 68 \mathrm{kDa}$ (wild-type subunit protein), a main band at $\sim 58 \mathrm{kDa}$ (mutant subunit protein) and sometimes a band at $\sim 45$ $\mathrm{kDa}$ (unglycosylated form of the mutant subunit protein). When normalized to the total $\gamma 2 S$ subunit protein obtained with wild-type expression, total wild-type $\gamma 2 S^{\mathrm{YFP}}$ subunit protein obtained with heterozygous subunit expression was reduced to less than half of total $\gamma 2 S^{\text {YFP }}$ subunit protein obtained with wild-type receptor expression.

To determine the maturation of $\gamma 2 \mathrm{~S}$ and $\gamma 2 \mathrm{~S}(\mathrm{Q} 351 \mathrm{X})$ subunit proteins when coexpressed with $\alpha 1$ and $\beta 2$ subunits in HEK 293-T cells, total wild-type $\gamma 2 S^{\mathrm{YFP}}$ and homozygous mutant $\gamma 2 \mathrm{~S}(\mathrm{Q} 351 \mathrm{X})^{\mathrm{YFP}}$ subunit proteins were analyzed with and without digestion with Endo-H (H) or PNGase F (F). Endo-H removes high-mannose $N$-linked carbohydrates attached in the ER but not those attached in the trans-Golgi region. In contrast, PNGase F removes all carbohydrates attached in both ER and trans-Golgi regions. The undigested $\gamma 2 S^{\mathrm{YFP}}$ subunit protein migrated primarily in one band at $\sim 68 \mathrm{kDa}$ (Fig. $6 \mathrm{~B}, \mathrm{U}$ ), and the undigested $\gamma 2 \mathrm{~S}(\mathrm{Q} 351 \mathrm{X})^{\mathrm{YFP}}$ subunit protein migrated primarily in a band at $\sim 58 \mathrm{kDa}$ (Fig. 6C, U). With Endo-H digestion, the $\gamma 2 \mathrm{~S}^{\mathrm{YFP}}$ subunit protein migrated in two strong bands (Fig. $6 \mathrm{~B}, \mathrm{H}$ ), a molecular mass shift that was consistent with a previous report (Connolly et al., 1996), and the $\gamma 2 \mathrm{~S}(\mathrm{Q} 351 \mathrm{X})^{\mathrm{YFP}}$ subunit protein migrated primarily in the same single band, suggesting that the majority of the mutant protein was retained inside the ER and only had immature ER glycosylation (Fig. 6C, H). With PNGase F digestion, both $\quad \gamma 2 \mathrm{~S}^{\mathrm{YFP}}$ and $\gamma 2 \mathrm{~S}(\mathrm{Q} 351 \mathrm{X})^{\mathrm{YFP}}$ subunit proteins migrated in one band (Fig. 6B, C, F in both panels) that was at the molecular mass of their Endo-H-sensitive bands. The Endo$\mathrm{H}$-insensitive $\gamma 2 \mathrm{~S}^{\mathrm{YFP}}$ subunit upper band represented the protein trafficked beyond the ER to the trans-Golgi and surface membrane, and the Endo-H-sensitive $\gamma 2 S^{\mathrm{YFP}}$ lower band represented the portion of wild-type $\gamma 2 S^{\text {YFP }}$ subunit that had not exited the ER. With the $\gamma 2 \mathrm{~S}(\mathrm{Q} 351 \mathrm{X})^{\text {YFP }}$ subunit, Endo-H digestion shifted the main band to the same level obtained with PNGase F digestion, suggesting that when coexpressed with $\alpha 1$ and $\beta 2$ subunits, $\gamma 2 \mathrm{~S}(\mathrm{Q} 351 \mathrm{X})$ subunit protein underwent ER, but not Golgi, glycosylation.

We also compared the total expression and Endo-H sensitivity of wild-type $\gamma 2 \mathrm{~S}$ subunits in the hemizygous expression condition (hem; $\mathrm{U}, \mathrm{H}, \mathrm{F}$ ) with those in the presence of mutant $\gamma 2 \mathrm{~S}(\mathrm{Q} 351 \mathrm{X})$ subunits (het; U, H, F). Hemizygous $\gamma 2 S^{\mathrm{GFP}}$ or $\gamma 2 \mathrm{~S}^{\mathrm{HA}}$ and heterozygous $\gamma 2 \mathrm{~S}^{\mathrm{GFP}} /$ $\gamma 2 \mathrm{~S}(\mathrm{Q} 351 \mathrm{X})$ or $\gamma 2 \mathrm{~S}^{\mathrm{HA}} / \gamma 2 \mathrm{~S}(\mathrm{Q} 351 \mathrm{X})$ subunits were coexpressed with $\alpha 1$ and $\beta 2$ subunits. To discriminate between the two types of subunit since the molecular masses of the unglycosylated wild-type subunit and mutant subunit were similar, only wild-type $\gamma 2 S$ subunits were tagged. The smaller HA epitope was included to exclude alteration of trafficking due to YFP epitope tagging. Empty pcDNA vector was used to normalize the total amount of transfected cDNA in the hemizygous condition. In the presence of mutant $\gamma 2 \mathrm{~S}(\mathrm{Q} 351 \mathrm{X})$ subunits, both the total and Endo-H-insensitive amounts of wild-type $\gamma 2 S^{\mathrm{YFP}}$ were reduced compared with the hemizygous condition (Fig. $6 D, E$ ). The fraction of total $\gamma 2 S^{\text {YFP }}$ subunit protein that was Endo-H insensitive with wild-type subunit expression $(0.40 \pm 0.08)$ (Fig. $6 B, E)$ or hemizygous control subunit expression $(0.52 \pm 0.03)$ (Fig. $6 D, E)$ were not significantly different. However, with heterozygous subunit expression (Fig. $6 D$ ), the Endo-H-insensitive fraction of $\gamma 2 S^{\mathrm{YFP}}$ protein was reduced compared with wild-type (Fig. $6 \mathrm{~B}$ ) and hemizygous control (Fig. $6 D)$ subunits $(0.15 \pm 0.04 ; p=0.03$ vs wt; $p<0.0001$ vs hem) (Fig. 6E). With homozygous subunit expression there was minimal Endo-H-insensitive $\gamma 2 \mathrm{~S}(\mathrm{Q} 351 \mathrm{X})^{\mathrm{YFP}}$ subunit protein $(0.02 \pm 0.007)$ (Fig. 6C,E). Together, these experiments demonstrated that with homozygous or heterozygous expression, the $\gamma 2 \mathrm{~S}(\mathrm{Q} 351 \mathrm{X})$ subunit had immature glycosylation and did not traffic to the cell surface, and with heterozygous expression, the wild-type $\gamma 2$ subunit also had less mature glycosylation and reduced trafficking to the cell surface.

The $\gamma 2 S(\mathrm{Q} 351 \mathrm{X})$ subunit oligomerized with and reduced the trafficking of $\alpha 1$ and $\beta 2$ subunits

The above data demonstrated that although truncated $\gamma 2 S(Q 351 X)$ subunits were expressed, they were retained in the ER and not trafficked to the cell surface and that coexpression of heterozygous $\gamma 2 \mathrm{~S} / \gamma 2 \mathrm{~S}(\mathrm{Q} 351 \mathrm{X})$ subunits with $\alpha 1$ and $\beta 2$ sub- 
units resulted in current that was less than half of wild-type receptor current and less than hemizygous receptor current. These findings suggested that mutant subunits may oligomerize with $\alpha 1$ and $\beta 2$ subunits and/or impair their ability to assemble with $\gamma 2 \mathrm{~S}$ subunits, resulting in fewer surface wild-type $\alpha 1 \beta 2 \gamma 2 \mathrm{~S}$ receptors. To determine whether $\gamma 2 \mathrm{~S}(\mathrm{Q} 351 \mathrm{X})$ subunits can assemble with $\alpha 1$ and $\beta 2$ subunits, $\beta 2$ subunits and fluorescent enhanced cyan fluorescent protein (CFP)-tagged $\alpha 1 \quad\left(\alpha 1^{\mathrm{CFP}}\right)$ subunits were coexpressed in COS-7 cells with or without $\gamma 2 S$ or $\gamma 2 \mathrm{~S}(\mathrm{Q} 351 \mathrm{X})$ subunits (Fig. 7). If assembled, were the mutant receptors retained in the ER? If assembly did not occur, were $\alpha 1 \beta 2$ receptors formed and trafficked to the cell surface? Coexpression of $\alpha 1^{\mathrm{CFP}}$ and $\beta 2$ subunits alone (Fig. 7A, left) or with $\gamma 2 \mathrm{~S}$ subunits (Fig. 7A, middle) resulted in localization of $\alpha 1^{\mathrm{CFP}}$ subunits on the cell surface. In contrast, with coexpression of $\alpha 1^{\mathrm{CFP}}$, $\beta 2$, and $\gamma 2 \mathrm{~S}(\mathrm{Q} 351 \mathrm{X})$ subunits, $\alpha 1^{\mathrm{CFP}}$ subunits were localized primarily intracellularly (Fig. $7 A$, right), suggesting that $\gamma 2 \mathrm{~S}(\mathrm{Q} 351 \mathrm{X})$ subunits oligomerized with $\alpha 1$ subunits and prevented them from oligomerizing with $\beta 2$ subunits, and/or directly oligomerized with $\beta 2$ subunits, and thus prevented assembly of $\alpha 1 \beta 2$ receptors.

We then compared $\alpha 1$ subunit surface protein detected using biotinylation following coexpression of $\alpha 1$ and $\beta 2$ subunits or of $\alpha 1$ and $\beta 2$ subunits with wild-type $\gamma 2 S$, hemizygous $\gamma 2 S$, heterozygous $\gamma 2 \mathrm{~S} / \gamma 2 \mathrm{~S}(\mathrm{Q} 351 \mathrm{X})$, or homozygous $\gamma 2 \mathrm{~S}(\mathrm{Q} 351 \mathrm{X})$ subunits (Fig. 7B). Surface $\alpha 1$ subunit levels were high with expression of $\alpha 1 \beta 2$ (taken as 1$)$ and $\alpha 1 \beta 2 \gamma 2 \mathrm{~S}(0.93 \pm 0.06, n=5)$ subunits and with coexpression of hemizygous $\gamma 2 S$ subunits with $\alpha 1$ and $\beta 2$ subunits $(0.99 \pm$ $0.01, n=4$ ) (Fig. 7C). Surface $\alpha 1$ subunit protein levels were reduced slightly but significantly with heterozygous $\gamma 2 S / \gamma 2 S(Q 351 X)$ subunit expression $(0.77 \pm 0.04 n=6, p=0.038$ vs wt; $p=0.002$ vs hem) when compared with either wild-type or hemizygous $\gamma 2 \mathrm{~S}$ subunit expression and were reduced substantially with homozygous $\gamma 2 \mathrm{~S}(\mathrm{Q} 351 \mathrm{X})$ subunit expression $(0.37 \pm 0.02, n=8, p<0.0001$ vs wt) when compared with all other conditions (Fig. 7C). However, there was a quantitative discrepancy between the loss of surface $\alpha 1$ subunit and the peak current in the heterozygous condition. This probably suggests that there are other unknown mechanisms involved in the receptor trafficking and function in the presence of the mutant protein. In addition, it is unknown about the ratio of $\alpha 1 \beta 2$ versus $\alpha 1 \beta 2 \gamma 2 \mathrm{~S}$ receptors on the surface in the heterozygous condition. $\alpha 1 \beta 2$ and $\alpha 1 \beta 2 \gamma 2 S$ receptors have different channel conductance and kinetics, thus resulting in different current amplitudes. The discrepancy could also be due to the fact that both Western blot and whole-cell recording are poorly quantitative techniques.

We then compared the whole-cell current amplitudes from receptor channels formed by expression of $\alpha 1$ and $\beta 2$ subunits with or without the $\gamma 2 \mathrm{~S}(\mathrm{Q} 351 \mathrm{X})$ subunit. Currents recorded with $\alpha 1 \beta 2 \gamma 2 \mathrm{~S}(\mathrm{Q} 351 \mathrm{X})$ subunit transfection $(75.1 \pm 23.6 \mathrm{pA}$, $n=62$ ) were much smaller than those recorded with $\alpha 1 \beta 2$ subunit transfection $(219.9 \pm 25 \mathrm{pA}, n=19 ; p<0.0001)$ (Fig. $7 D)$ or with $\alpha 1 \beta 2 \gamma 2 S$ subunit transfection ( $4161 \pm 852 \mathrm{pA}, n=17$ ) (Fig. $2 A, B)$. Two types of currents were obtained following $\alpha 1 \beta 2 \gamma 2 S(\mathrm{Q} 351 \mathrm{X})$ subunit transfection and both were small and ran-down rapidly (data not shown). In addition, incremental increases in the $\alpha 1 \beta 2 \gamma 2 \mathrm{~S}(\mathrm{Q} 351 \mathrm{X})$ subunit cDNA ratios from 1:1:1 to $1: 1: 10$ resulted in a $\gamma 2 \mathrm{~S}(\mathrm{Q} 351 \mathrm{X})$ subunit cDNA concentrationdependent loss of the small current (Fig. 7D) although the total cDNA amounts were normalized by adding the empty vector pcDNA.

What was the basis for $\gamma 2 \mathrm{~S}(\mathrm{Q} 351 \mathrm{X})$ subunits causing retention of wild-type $\alpha 1, \beta 2$, and $\gamma 2 \mathrm{~S}$ subunits? Does the $\gamma 2 \mathrm{~S}(\mathrm{Q} 351 \mathrm{X})$ subunit oligomerize with $\alpha 1$ and $\beta 2$ subunits? To determine this we coexpressed FLAG-tagged $\gamma 2 \mathrm{~S}\left(\gamma 2 \mathrm{~S}^{\mathrm{FLAG}}\right)$ and $\gamma 2 \mathrm{~S}(\mathrm{Q} 351 \mathrm{X})^{\mathrm{FLAG}}$ subunits with $\alpha 1$ and $\beta 2$ subunits in HEK 293-T cells and purified the $\gamma 2 S^{\mathrm{FLAG}}$ and $\gamma 2 \mathrm{~S}(\mathrm{Q} 351 \mathrm{X})^{\mathrm{FLAG}}$ subunits from the total lysates with FLAG-conjugated beads. The protein that was pulled down was probed with either anti- $\alpha 1$ or anti- $\beta 2$ antibody. In both $\gamma 2 S$ (wt) and $\gamma 2 \mathrm{~S}(\mathrm{Q} 351 \mathrm{X})$ (hom) protein complexes, $\alpha 1$ (Fig. 7E, left) or $\beta 2$ subunits (Fig. 7E, right) were detected, suggesting that the $\gamma 2 \mathrm{~S}(\mathrm{Q} 351 \mathrm{X})$ subunit oligomerized with both $\alpha 1$ and $\beta 2$ subunits. Similarly, we cotransfected wild-type and mutant $\gamma 2 S$ subunits tagged with either the FLAG or HA tag (i.e., $\gamma 2 \mathrm{~S}^{\mathrm{FLAG}}$ and $\gamma 2 \mathrm{~S}(\mathrm{Q} 351 \mathrm{X})^{\mathrm{HA}}$ or $\gamma 2 \mathrm{~S}^{\mathrm{HA}}$ and $\gamma 2 \mathrm{~S}(\mathrm{Q} 351 \mathrm{X})^{\text {FLAG }}$ subunits) with $\alpha 1$ and $\beta 2$ subunits. We then pulled down the total protein with antiFLAG antibody and blotted with HA. In each heterozygous condition, the $\gamma 2 \mathrm{~S}^{\mathrm{HA}}$ or $\gamma 2 \mathrm{~S}(\mathrm{Q} 351 \mathrm{X})^{\mathrm{HA}}$ subunit protein was detected, suggesting that the mutant $\gamma 2 \mathrm{~S}(\mathrm{Q} 351 \mathrm{X})$ subunit also oligomerized with the wild-type $\gamma 2 S$ subunit (Fig. 7F).

\section{$\alpha 1$ subunits were retained in the ER and had accelerated degradation in the presence of $\gamma 2 \mathrm{~S}(\mathrm{Q} 351 \mathrm{X})$ subunits}

Reduction of $\alpha 1$ and $\beta 2$ subunits on the surface produced by coexpression with $\gamma 2 \mathrm{~S}(\mathrm{Q} 351 \mathrm{X})$ subunits could be caused by reduction of total cellular subunit proteins due to accelerated degradation or by ER retention and failure of subunit maturation. We thus determined total expression and glycosylation of wildtype subunits by Western blot and Endo-H digestion. In HEK 293-T cells following coexpression of $\alpha 1$ and $\beta 2$ subunits with wild-type $\gamma 2 \mathrm{~S}$, hemizygous control $\gamma 2 \mathrm{~S}$, heterozygous $\gamma 2 \mathrm{~S} /$ $\gamma 2 \mathrm{~S}(\mathrm{Q} 351 \mathrm{X})$, or homozygous $\gamma 2 \mathrm{~S}(\mathrm{Q} 351 \mathrm{X})$ subunits, total $\alpha 1$ subunit proteins were undigested $(\mathrm{U})$ or digested $(\mathrm{H})$ with Endo-H (Fig. 8 A). GAPDH was used as the gel loading control, and $\alpha 1$ subunit protein levels were expressed as $\alpha 1$ subunit/ GAPDH IDV ratios normalized to wild-type receptor (Fig. $8 B$ ). With heterozygous $\gamma 2 \mathrm{~S} / \gamma 2 \mathrm{~S}(\mathrm{Q} 351 \mathrm{X})$ subunit expression, total $\alpha 1$ subunit protein $(85.7 \pm 14.28)$ was slightly, but not significantly, reduced compared with wild-type $\alpha 1$ subunit expression ( $p=0.50, n=5$ ) but was reduced compared with hemizygous control $\gamma 2 \mathrm{~S}$ subunit expression $(138.79 \pm 10.22)(p=0.02)$. With homozygous $\gamma 2 \mathrm{~S}(\mathrm{Q} 351 \mathrm{X}$ ) subunit expression, total $\alpha 1$ subunit protein was reduced $(24.49 \pm 6.12)$ compared with that with either wild-type $\gamma 2 \mathrm{~S}(p=0.002)$ or heterozygous $\gamma 2 \mathrm{~S} /$ $\gamma 2 \mathrm{~S}(\mathrm{Q} 351 \mathrm{X})(p=0.004)$ subunit expression (Fig. $8 B$ ). These data demonstrated that there was a small decrease in total $\alpha 1$ subunit protein with heterozygous $\gamma 2 \mathrm{~S} / \gamma 2 \mathrm{~S}(\mathrm{Q} 351 \mathrm{X})$ subunit expression, and a large decrease in total $\alpha 1$ subunit protein with homozygous $\gamma 2 \mathrm{~S}(\mathrm{Q} 351 \mathrm{X})$ subunit expression.

The reduction of $\alpha 1$ subunit protein was likely due to ER retention and subsequent ERAD. We therefore studied the effect of expression of the $\gamma 2 \mathrm{~S}(\mathrm{Q} 351 \mathrm{X})$ subunit on maturation of $\alpha 1$ subunit protein by characterizing its glycosylation pattern (Fig. $8 A, C)$ by using digestion with Endo-H. With coexpression of wild-type subunits, Endo-H digestion shifted the $\alpha 1$ subunit molecular mass from 50 to $48.4 \mathrm{kDa}$ and also to $46 \mathrm{kDa}$ depending on different transfection methods (data not shown). The presence of a $46 \mathrm{kDa}$ band with expression of wild-type subunits was likely caused by the excess protein production partially overwhelming the cellular glycosylation machinery with a high efficient transfection system. The $48.4 \mathrm{kDa}$ band represented the mature subunit trafficked beyond the trans-Golgi region, and the $46 \mathrm{kDa}$ band represented the immature subunit protein in the ER (Gallagher et al., 2005). With Endo-H digestion, most $\alpha 1$ subunits expressed with either wild-type or hemizygous control $\gamma 2 \mathrm{~S}$ subunits migrated in the $48.4 \mathrm{kDa}$ band with only a very small portion migrating in the immature $46 \mathrm{kDa}$ band $(48.4 \mathrm{kDa} /$ total $=$ 
A $\quad \alpha 1^{\mathrm{CFP}} \beta 2$

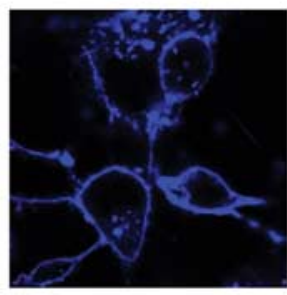

$\alpha 1^{\mathrm{CFP}} \beta 2 \gamma 2$

$\alpha 1^{\mathrm{CFP}} \beta 2 \gamma 2(\mathrm{Q} 351 \mathrm{X})$

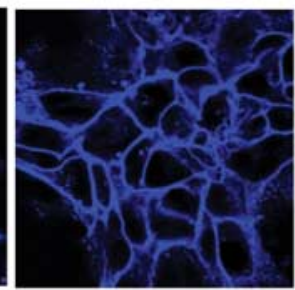

COS-7 cells

B

mock $\alpha 1 \beta 2 \quad \alpha 1 \beta 2 \gamma 2 \mathrm{~S} / \gamma 2 \mathrm{~S}(\mathrm{Q} 351 \mathrm{X})$

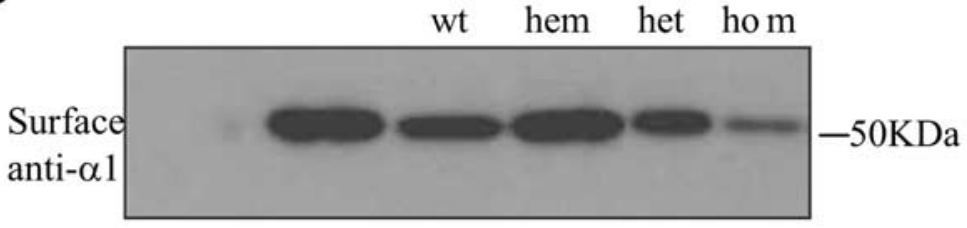

HEK 293-T cells

C

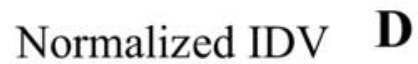
surface $\alpha 1$
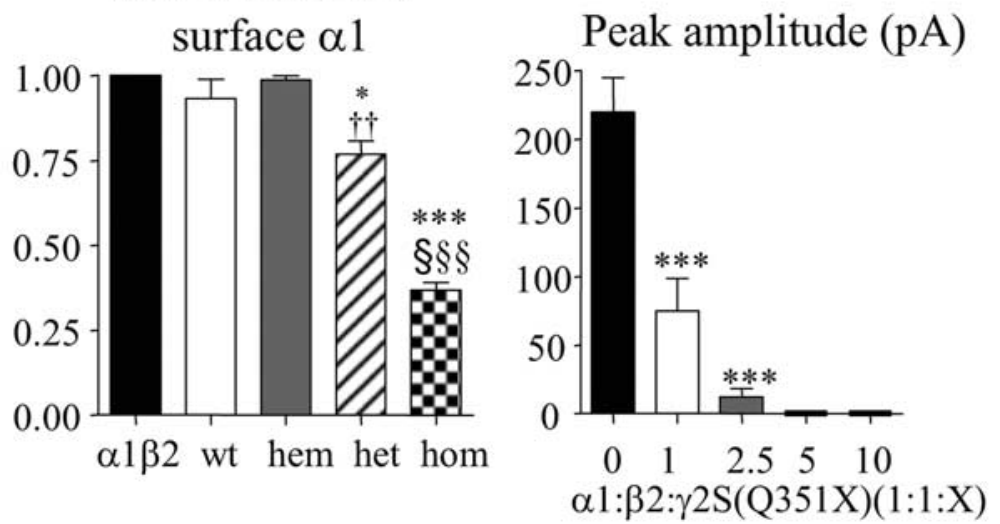

E

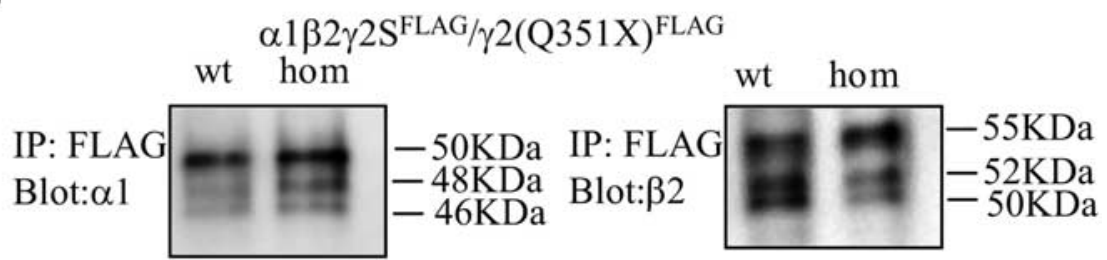

$\mathbf{F}$

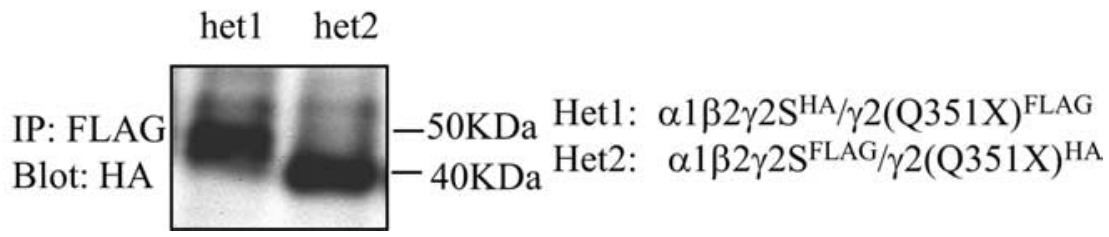

Figure 7. The truncated $\gamma 2 \mathrm{~S}(\mathrm{Q} 351 \mathrm{X})$ subunit impaired trafficking of $\alpha 1 \beta 2$ receptors to the cell surface due to its oligomerization with wild-type subunits. $\boldsymbol{A}$, COS-7 cells were transfected with $\alpha 1^{\mathrm{CFP}} \beta 2$ (left), $\alpha 1^{\mathrm{CFP}} \beta 2 \gamma 2 S$ (middle), or $\alpha 1^{\mathrm{CFP}} \beta 2 \gamma 2 \mathrm{~S}(\mathrm{Q} 351 \mathrm{X})$ subunits, and the confocal images were obtained $48 \mathrm{~h}$ later. B, HEK 293-T cells were transfected with empty pcDNA vector (mock) or with $\alpha 1 \beta 2$ (1:1 CDNA ratio), $\alpha 1 \beta 2 \gamma 2 S$ (1:1:1 CDNA ratio, wt), $\alpha 1 \beta 2 \gamma 2 S$ (1:1:0.5 CDNA ratio, hem), $\alpha 1 \beta 2 \gamma 2 S / \gamma 2 S(0351 X)$ (1:1:0.5:0.5 CDNA ratio, het), or $\alpha 1 \beta 2 \gamma 2 S(0351 X)$ (1:1:1 CDNA ratio) subunits, and surface proteins were prepared as described in the methods and visualized with anti-human $\alpha 1$ subunit antibody. C, Surface protein IDVs were normalized to $\alpha 1 \beta 2$ receptors $(n=4-8)\left({ }^{*} p<0.05,{ }^{* * *} p<0.001\right.$ vs wt; ${ }^{\circ \dagger} p<0.01$ vs hem; ${ }^{\S \S \S} p<0.001$ vs $\left.\alpha 1 \beta 2\right)$. Values were mean \pm SEM. D, HEK 293-T cells were transfected with $\alpha 1 \beta 2$ (1:1 cDNA ratio) or $\alpha 1 \beta 2 \gamma 2 S$ (Q351X) (1:1:1, 1:1:2.5, 1:1:5, 1:1:10 CDNA ratio) subunits, and the peak current amplitudes were plotted ( ${ }^{* * *} p<0.0001$ vs $\alpha 1 \beta 2$ ) $[n=19$ for $\alpha 1 \beta 2, n=62$ for $\alpha 1 \beta 2 \gamma 25(0351 X)(1: 1: 1), n=16$ for $\alpha 1 \beta 2 \gamma 2 S(0351 X)$ (1:1:2.5), $n=5$ for $\alpha 1 \beta 2 \gamma 2 S(0351 X)$ (1:1:5 and 1:1:10)]. Values were mean $\pm S D$. In $\boldsymbol{A}-\boldsymbol{D}$, the total amounts of cDNAs were normalized by the empty vector pcDNA. $\boldsymbol{E}$, Total lysates from HEK 293-T cells expressing $\alpha 1 \beta 2 \gamma 2 S^{\mathrm{FLAG}}$ or $\alpha 1 \beta 2 \gamma 2 \mathrm{~S}(\mathrm{Q} 351 \mathrm{X})^{\mathrm{FLAG}} \quad(1: 1: 1 \quad \mathrm{DNA}$ ratio) subunits were purified with agarose-
$95 \pm 4 \%$ for wt and $97 \pm 6.9$ for hem) (Fig. $8 \mathrm{~A}, \mathrm{C})$. However, the ratio of $48.4 \mathrm{kDa} / \mathrm{to}-$ tal bands was decreased with heterozygous $\gamma 2 \mathrm{~S} / \gamma 2 \mathrm{~S}(\mathrm{Q} 351 \mathrm{X})$ subunit expression $(62.9 \pm 9)$ and was decreased even more with homozygous $\gamma 2 \mathrm{~S}(\mathrm{Q} 351 \mathrm{X})$ subunit expression $(51 \pm 1.9)$ (Fig. $8 C$ ). These results suggested that increased mutant $\gamma 2$ subunits decreased maturation of $\alpha 1$ subunits, consistent with ER retention. To further confirm the dominant-negative effect of the $\gamma 2 \mathrm{~S}(\mathrm{Q} 351 \mathrm{X})$ subunit on $\alpha 1 \mathrm{sub}$ units, we transfected HEK 293-T cells with $\alpha 1 \beta 2 \gamma 2 S(\mathrm{Q} 351 \mathrm{X})$ subunits at cDNA ratios of $1: 1: 1,1: 1: 5$, and $1: 1: 10$ (Fig. $8 D$ ). With increasing $\gamma 2 \mathrm{~S}(\mathrm{Q} 351 \mathrm{X})$ subunit cDNA concentration, there was a progressive reduction of total $\alpha 1$ subunit protein (data not shown) and reduction of mature relative to immature $\alpha 1$ subunit protein (Fig. 8E).

What is the basis for the reduction of the wild-type partnering subunits? We determined how rapid wild-type $\alpha 1$ subunits were degraded when expressed with the mutant $\gamma 2 \mathrm{~S}(\mathrm{Q} 351 \mathrm{X})$ subunits, and whether the reduction of wild-type $\alpha 1$ and $\beta 2$ subunits was through ubiquitinproteosome degradation. HEK 293-T cells were cotransfected with $\alpha 1$ and $\beta 2$ subunits and wild-type $\gamma 2 \mathrm{~S}$ or mutant $\gamma 2 \mathrm{~S}(\mathrm{Q} 351 \mathrm{X})$ subunits. For pulse-chase experiments, $\alpha 1^{\text {FLAG }}$ subunits were radiolabeled with ${ }^{35} \mathrm{~S}$ and purified with FLAG M2 antibody-conjugated beads. Wild-type $\alpha 1^{\text {FLAG }}$ subunits were substantially reduced in the presence of mutant $\gamma 2 \mathrm{~S}(\mathrm{Q} 351 \mathrm{X})$ subunits compared with the presence of wild-type $\gamma 2$ subunits with either a $1 \mathrm{~h}(100 \mathrm{vs} 33.19 \pm 3.7 \%)$ or $3 \mathrm{~h}(100$ vs $47.81 \pm 4.7 \%$ ) chase (Fig. $8 F, G$ ), suggesting that degradation of wild-type $\alpha 1^{\text {FLAG }}$ subunits occurred rapidly. The proteasomal inhibitor, lactacystin $(10 \mu \mathrm{M}$, $6 \mathrm{~h}$ ), increased $\alpha 1^{\mathrm{FLAG}}$ subunit levels when coexpressed with either wild-type $\gamma 2 \mathrm{~S}$ or mutant $\gamma 2 \mathrm{~S}(\mathrm{Q} 351 \mathrm{X})$ subunits (Fig. 8H). However, total $\alpha 1$ subunits increased to a greater extent with mutant $\gamma 2 \mathrm{~S}(\mathrm{Q} 351 \mathrm{X})$ subunits $(176.4 \pm 10.29 \%, n=5)$ than with wild-type $\gamma 2 \mathrm{~S}$ subunits (122.2 \pm $3.6 \%, n=5)$, suggesting that $\alpha 1$ subunits were subject to enhanced proteasomal

$\leftarrow$

immobilized anti-FLAG M2 antibody, and the conjugated subunits were liberated with FLAG-peptide and probed with anti- $\alpha 1$ ( $\boldsymbol{E}$, left) or anti- $\beta 2$ (E, right). $\boldsymbol{F}$, Total lysates from HEK 293-T cells expressing $\alpha 1 \beta 2 \gamma 22^{\mathrm{HA}} / \gamma 2 S(\mathrm{Q} 351 \mathrm{X})^{\text {FLAG }}$ (het1) or $\alpha 1 \beta 2 \gamma 2 S^{\mathrm{FLAG}} / \gamma 2 \mathrm{~S}(\mathrm{Q} 351 \mathrm{X})^{\mathrm{HA}}$ (het 2) (1:1:0.5:0.5) were purified with FLAG M2 antibody as described in $\boldsymbol{E}$ and visualized with anti-HA antibody. 
A

$$
\text { Total } \alpha 1 \text { subunit protein }
$$
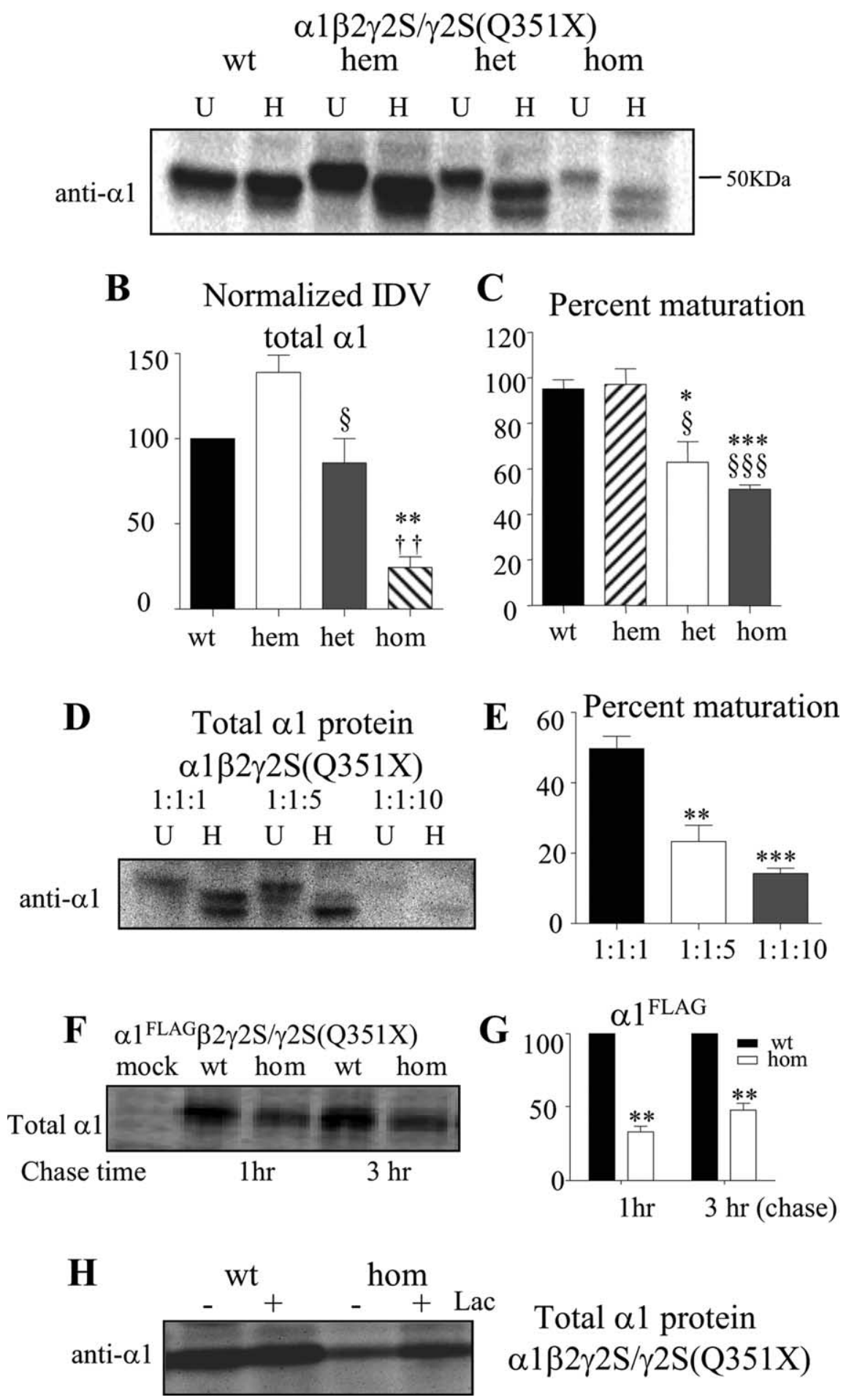

Figure 8. The $\alpha 1$ subunit was subject to glycosylation arrest and enhanced degradation in the presence of the $\gamma 2 S(Q 351 X)$ subunit. $A$, HEK 293-T cells were cotransfected with $\alpha 1$ and $\beta 2$ subunits and wild-type $\gamma 2 S$ (1:1:1 wt or 1:1:0.5 hem cDNA ratio), heterozygous $\gamma 2 S / \gamma 2 S(0351 X)$ (1:1:0.5:0.5 hem cDNA ratio), and homozygous $\gamma 2 S(0351 X)$ (1:1:1 cDNA ratio) subunits. The cell lysates were either undigested $(\mathrm{U})$ or digested with Endo-H $(\mathrm{H})$ and analyzed by SDS-PAGE. $\boldsymbol{B}$, Total undigested $\alpha 1$ subunit protein IDVs were quantified, and the data were normalized to GAPDH IDVs $(n=5)$. C, The fractions of Endo-H-digested $\alpha 1$ subunit proteins were quantified and expressed as percentage maturation [taken as $100 \%$ if there was only a single $48.4 \mathrm{kDa}$ present and a percentage of the $48.4 \mathrm{kDa}$ band $(\boldsymbol{A}$, top lanes in $\mathrm{H})$ over 48.4 plus $46 \mathrm{kDa}$ bands $(\boldsymbol{A}$, bottom lanes in $\mathrm{H})$ if there were two bands present]. In $B$ and $C,{ }^{*} p<0.05,{ }^{* *} p<0.01,{ }^{* * *} p<0.001$ versus wt; ${ }^{{ }^{* \dagger}} p<0.01$ versus het $0.5 ;{ }^{{ }^{*}} p<0.05,{ }^{\S \S} p<0.01,{ }^{\S \S \S} p<$ 0.001 versus hemizygous control $(n=5)$. D, HEK 293-T cells were cotransfected with $\alpha 1, \beta 2$, and $\gamma 2 S(Q 351 X)$ subunits using CDNA ratios of 1:1:1, 1:1:5, and 1:1:10. The lysates were either undigested $(\mathrm{U})$ or digested with Endo- $\mathrm{H}(\mathrm{H})$ and analyzed by $10 \%$ SDS-PAGE. $\boldsymbol{E}$, The fractions of Endo-H-digested $\alpha 1$ subunit protein IDVs were quantified as described in $\mathbf{C}$. In $\boldsymbol{A}-\boldsymbol{E}$, the total

degradation in the presence of $\gamma 2 \mathrm{~S}(\mathrm{Q} 351 \mathrm{X})$ subunits.

\section{Discussion}

The $\gamma 2$ subunit mutation, Q351X, produced a truncated subunit protein with loss of function

The $\gamma 2$ subunit mutation, Q351X, is in the last exon of a 9 exon gene, and thus, should not activate NMD but should allow translation of a truncated protein. Using an intron 8 minigene construct, we demonstrated that truncated $\gamma 2(\mathrm{Q} 351 \mathrm{X})$ subunits were produced and that wholecell levels were actually higher than those of wild-type $\gamma 2$ subunits. However, despite the presence of large amounts of mutant subunits, they only attained immature, core glycosylation, were retained in the ER and were not trafficked to the cell surface when coexpressed with $\alpha 1$ and $\beta 2$ subunits. As a result, currents recorded with coexpression of $\alpha 1$ and $\beta 2$ subunits and heterozygous $\gamma 2 \mathrm{~S} / \gamma 2 \mathrm{~S}(\mathrm{Q} 351 \mathrm{X})$ subunits were smaller than those produced with coexpression of wild-type $\alpha 1, \beta 2$, and $\gamma 2 S$ subunits. Thus, the $\gamma 2$ subunit mutation, Q351X, is a loss-of-function mutation.

The $\gamma 2 \mathrm{~S}(\mathrm{Q} 351 \mathrm{X})$ subunit had a dominant-negative effect on partnering wild-type $\alpha 1$ and $\beta 2$ subunits and on $\gamma 2 S$ subunits leading to reduction in surface expression of $\alpha 1 \beta 2 \gamma 2 S$ and $\alpha 1 \beta 2$ receptors

Because the $\gamma 2$ subunit mutation, Q351X, is a loss-of-function mutation, this autosomal dominant disease could result from $\gamma 2$ subunit hemizygosity. However, the heterozygous, haploinsufficient $\gamma 2$ subunit knock-out mouse had a phenotype of hyper-anxiety, not epilepsy (Crestani et al., 1999), suggesting a relatively mild functional compromise of $\mathrm{GABA}_{\mathrm{A}}$ ergic inhibition. Our data also suggested that the

\footnotetext{
$\leftarrow$

amounts of $c D N A s$ were normalized by the empty vector pcDNA. ${ }^{* *} p<0.01,{ }^{* * *} p<0.001$ versus $\alpha 1 \beta 2 \gamma 25$ (Q351X) $(1: 1: 1)(n=4) . F, G$, HEK 293-T cells containing ${ }^{35} S$ methionine-radiolabeled $\alpha{ }^{\mathrm{FLAG}} \beta 2 \gamma 2 \mathrm{~S}$ (wt) and $\alpha 1^{\text {FLAG }} \beta 2 \gamma 2 S(0351 X)$ (hom) receptors were lysed, immunopurified with FLAG M2 antibody, and analyzed by SDS-PAGE. After $20 \mathrm{~min}$ of labeling, the cells were chased for the indicated times $(n=4)$. The same amount of total protein $(800$ $\mu \mathrm{g})$ from each sample was used for immunopurification $(\boldsymbol{F})$. The graph plots the percentage radioactivity normalized to $\alpha 1^{\text {FLAG }}$ subunit IDV of $\alpha 1^{\text {FLAG }} \beta 2 \gamma 2 S$ receptors at the given chase time (G) ${ }^{* *} p<0.01$ vs $\left.\alpha 1^{\mathrm{FLAG}} \beta 2 \gamma 2 \mathrm{~S}\right)$. $\boldsymbol{H}$, The total lysates from cells expressing $\alpha 1 \beta 2 \gamma 2 S$ and $\alpha 1 \beta 2 \gamma 2 S(0351 \mathrm{X})$ receptors with or without treatment by lactacystin (Lac, $10 \mu \mathrm{m})$ for $6 \mathrm{~h}$ were analyzed by SDS-PAGE and blotted with anti- $\alpha 1$ antibody.
} 
functional impairment produced by a nonfunctional, truncated $\gamma 2 \mathrm{~S}(\mathrm{Q} 351 \mathrm{X})$ subunit in the heterozygous condition was more severe than in the haploinsufficient condition. With coexpression of heterozygous $\gamma 2 \mathrm{~S} / \gamma 2 \mathrm{~S}(\mathrm{Q} 351 \mathrm{X})$ subunits and $\alpha 1$ and $\beta 2$ subunits, currents and surface expression of $\alpha 1 \beta 2 \gamma 2$ receptors were reduced compared with the hemizygous control condition. Our study suggested that with heterozygous expression of $\gamma 2 \mathrm{~S} /$ $\gamma 2 \mathrm{~S}(\mathrm{Q} 351 \mathrm{X})$ subunits, the reduction of whole-cell current and surface $\alpha 1 \beta 2 \gamma 2$ receptors relative to hemizygous control receptors was due to a dominant-negative effect of $\gamma 2 \mathrm{~S}(\mathrm{Q} 351 \mathrm{X})$ subunits. We demonstrated that $\gamma 2 \mathrm{~S}(\mathrm{Q} 351 \mathrm{X})$ subunits oligomerized with $\alpha 1, \beta 2$, and $\gamma 2 S$ subunits to form oligomers that were trapped in the ER, thus impairing assembly and forward trafficking of $\alpha 1 \beta 2 \gamma 2 S$ receptors to the cell surface and resulting in reduced whole-cell current.

The dominant-negative effect of $\gamma 2 \mathrm{~S}(\mathrm{Q} 351 \mathrm{X})$ subunits on $\alpha 1$ and $\beta 2$ subunits was supported by both electrophysiological and Western blot results. With coexpression of $\gamma 2 S(\mathrm{Q} 351 \mathrm{X})$ subunits and $\alpha 1$ and $\beta 2$ subunits, only very small currents that "ran down" rapidly were recorded. These small currents were abolished by increasing the concentration of $\gamma 2 \mathrm{~S}(\mathrm{Q} 351 \mathrm{X})$ subunit cDNA. This, suggested that the small current was likely to be produced by "escape" of $\alpha 1 \beta 2$ receptors from trapping by $\gamma 2 \mathrm{~S}(\mathrm{Q} 351 \mathrm{X})$ subunits, and the increasing amount of mutant protein increasingly reduced surface expression $\alpha 1 \beta 2$ receptors. With coexpression of $\gamma 2 \mathrm{~S}(\mathrm{Q} 351 \mathrm{X})$ subunits and $\alpha 1$ and $\beta 2$ subunits, the wildtype partnering $\alpha 1$ and $\beta 2$ subunits had reduced maturation and were retained in the ER. Similarly, the biochemical data demonstrated that an incremental increase of $\gamma 2 \mathrm{~S}(\mathrm{Q} 351 \mathrm{X})$ subunits progressively diminished the total expression of $\alpha 1$ subunits. Finally, $\alpha 1, \beta 2$, and $\gamma 2 S$ subunits were all coimmunoprecipitated with mutant $\gamma 2(\mathrm{Q} 351 \mathrm{X})$ subunits. However, it is unclear whether oligomerization comes before glycosylation arrest, since both different glycosylated forms of $\alpha 1$ and $\beta 2$ subunits appeared to be pulled down by $\gamma 2 \mathrm{~S}(\mathrm{Q} 351 \mathrm{X})^{\mathrm{FLAG}}$ subunits. The dominantnegative effect of $\gamma 2 \mathrm{~S}(\mathrm{Q} 351 \mathrm{X})$ subunits on $\gamma 2 \mathrm{~S}$ subunits was supported by the observation that with heterozygous expression, less than one half of the total wild-type $\gamma 2 S$ subunit was found with $\alpha 1 \beta 2 \gamma 2 \mathrm{~S}$ receptor expression, and total wild-type $\gamma 2 \mathrm{~S}$ subunit levels were less than those of mutant subunits. In addition, wildtype and mutant $\gamma 2 \mathrm{~S}$ subunits were demonstrated to coimmunoprecipitate. Together, these data suggest that the $\gamma 2 \mathrm{~S}(\mathrm{Q} 351 \mathrm{X})$ subunit accumulated intracellularly and oligomerized with wildtype $\alpha 1, \beta 2$, and $\gamma 2 S$ subunits, thus impairing assembly and trafficking of wild-type receptors.

\section{Reduction of the total wild-type subunits was rapid and likely due to ERAD through the UPS}

ER quality control only allows correctly folded and assembled molecules to mature and traffic to later compartments of the secretory pathway (Ellgaard and Helenius, 2003). Misfolded wild-type and mutant proteins like the cystic fibrosis transmembrane conductance regulator are substrates for proteasomal degradation (Jensen et al., 1995; Ward et al., 1995). We recently demonstrated that the misfolded mutant $\mathrm{GABA}_{\mathrm{A}}$ receptor $\alpha 1(\mathrm{~A} 322 \mathrm{D})$ subunit was also degraded through the UPS (Gallagher et al., 2007). Here we show that in the presence of mutant $\gamma 2 \mathrm{~S}(\mathrm{Q} 351 \mathrm{X})$ subunits, wild-type partnering $\alpha 1$ subunits were subject to glycosylation arrest and degraded at least partially through the proteasomal system. We assume that the other wildtype partnering $\beta 2$ subunit was subject to the similar cellular fate, but the magnitude of reduction for each subunit may be different due to different protein metabolic kinetics demonstrated in our pulse-chase experiments (data not shown). A dominant-negative effect of mutant subunits on wild-type subunits has been observed with other ion channel proteins including calcium channels (Page et al., 2004) and potassium channels (Gong et al., 2004). The basis for the dominant-negative effect of mutant proteins on wild-type proteins in these channels involves multimerization of wild-type and mutant proteins (Aizawa et al., 2004; Gong et al., 2004) and the unfolded protein response including ERAD (Page et al., 2004; Mezghrani et al., 2008). The same mechanism of suppression of wild-type subunit maturation has also been reported in autosomal dominant retinitis pigmentosa ( $\mathrm{Ra}-$ jan and Kopito, 2005), thus suggesting that the promoted ERAD of wild-type protein may be a unifying mechanism underlying many dominant-negative diseases (Mezghrani et al., 2008). However, the lysosome pathway may also contribute to the reduction of the wild-type receptors in the presence of mutant $\gamma 2 S(\mathrm{Q} 351 \mathrm{X})$ subunits during receptor trafficking, endocytosis, and recycling, but this needs to be clarified.

\section{Heterozygous expression of nonfunctional $\gamma 2 \mathrm{~S}(\mathrm{Q} 351 \mathrm{X})$ subunits and hemizygous $\gamma 2 S$ subunits have different molecular pathologies}

The dominant-negative effect of $\gamma 2 S(\mathrm{Q} 351 \mathrm{X})$ subunits with heterozygous expression may explain why hemizygous GABRG2 $(+/-)$ gene-deletion and heterozygous $\gamma 2 \mathrm{~S}(\mathrm{Q} 351 \mathrm{X})$ mutation conditions are pathologically different. Although the mutant subunit is trafficking deficient, it can oligomerize with partnering wild-type subunits, thus preventing their maturation and promoting their degradation. This negative effect is not present in the hemizygous GABRG2 gene-deletion animal. In contrast, there is a small compensatory subunit increase in the hemizygous condition, resulting in slightly more than the half of the wild-type subunit expression. The underlying mechanisms could be related to the availability of chaperone proteins or other unknown reasons. The reason that $\gamma 2 \mathrm{~S}(\mathrm{Q} 351 \mathrm{X})$ subunits can oligomerize with wild-type subunits is probably due to their intact $\mathrm{N}$ termini, which have been demonstrated to mediate subunit assembly in both $\mathrm{GABA}_{\mathrm{A}}$ and nACh receptors (Verrall and Hall, 1992; Klausberger et al., 2001).

\section{$\alpha 1 \beta 2$ receptors were formed due to the decrease in available $\gamma 2 \mathrm{~S}$ subunits}

Our data on hemizygous control receptors and studies of the heterozygous $\gamma 2$ subunit knock-out mouse (Crestani et al., 1999) both suggested that $\alpha 1 \beta 2$ receptors are formed and trafficked to the surface with reduced expression of the $\gamma 2$ subunit. This suggests that $\alpha 1 \beta 2$ receptors will be formed if $\gamma 2$ subunits are reduced or unavailable, resulting in a slight compensation for the loss of $\mathrm{GABA}_{\mathrm{A}}$ ergic inhibition due to the decrease in available $\gamma 2 \mathrm{~S}$ subunits.

\section{$\gamma 2 S(Q 351 X)$ subunits result in both "loss of function" and "dominant-negative suppression"}

This study is the first report of dominant-negative suppression of a naturally occurring mutant $\mathrm{GABA}_{\mathrm{A}}$ receptor subunit protein. The mutant protein could have a "gain of toxic function" in addition to the loss of the function of the mutant allele itself. For example, the presence of the mutant protein caused more degradation of the wild-type subunits. This effect could be due to the direct interaction of the mutant and wild-type subunits or partially to the mutant protein triggering ER stress or the unfolded protein response. This response is to reduce the burden on the ER resulting from unfolded or trafficking deficient molecules 
through a series of cellular processes including inhibition of transcription, rescue of unfolded protein by increasing the expression of chaperones and ERAD (Hampton, 2000; Rao et al., 2004). Future study focusing on transcription, recycling, and degradation may further elucidate the underlying mechanisms of this trafficking deficient mutant in epileptogenesis.

\section{References}

Aizawa Y, Ueda K, Wu LM, Inagaki N, Hayashi T, Takahashi M, Ohta M, Kawano S, Hirano Y, Yasunami M, Aizawa Y, Kimura A, Hiraoka M (2004) Truncated KCNQ1 mutant, A178fs/105, forms hetero-multimer channel with wild-type causing a dominant-negative suppression due to trafficking defect. FEBS Lett 574:145-150.

Amrani N, Ganesan R, Kervestin S, Mangus DA, Ghosh S, Jacobson A (2004) A faux 3 '-UTR promotes aberrant termination and triggers nonsensemediated mRNA decay. Nature 432:112-118.

Audenaert D, Schwartz E, Claeys KG, Claes L, Deprez L, Suls A, Van Dyck T, Lagae L, Van Broeckhoven C, Macdonald RL, De Jonghe P (2006) A novel GABRG2 mutation associated with febrile seizures. Neurology 67:687-690.

Baulac S, Huberfeld G, Gourfinkel-An I, Mitropoulou G, Beranger A, Prud'homme JF, Baulac M, Brice A, Bruzzone R, LeGuern E (2001) First genetic evidence of $\mathrm{GABA}_{\mathrm{A}}$ ) receptor dysfunction in epilepsy: a mutation in the gamma2-subunit gene. Nat Genet 28:46-48.

Bianchi MT, Song L, Zhang H, Macdonald RL (2002) Two different mechanisms of disinhibition produced by $\mathrm{GABA}_{\mathrm{A}}$ receptor mutations linked to epilepsy in humans. J Neurosci 22:5321-5327.

Connolly CN, Krishek BJ, McDonald BJ, Smart TG, Moss SJ (1996) Assembly and cell surface expression of heteromeric and homomeric gammaaminobutyric acid type A receptors. J Biol Chem 271:89-96.

Crestani F, Lorez M, Baer K, Essrich C, Benke D, Laurent JP, Belzung C, Fritschy JM, Lüscher B, Mohler H (1999) Decreased GABA ${ }_{A}$-receptor clustering results in enhanced anxiety and a bias for threat cues. Nat Neurosci 2:833-839.

Ellgaard L, Helenius A (2003) Quality control in the endoplasmic reticulum. Nat Rev Mol Cell Biol 4:181-191.

Essrich C, Lorez M, Benson JA, Fritschy JM, Lüscher B (1998) Postsynaptic clustering of major GABAA receptor subtypes requires the gamma 2 subunit and gephyrin. Nat Neurosci 1:563-571.

Feng HJ, Kang JQ, Song L, Dibbens L, Mulley J, Macdonald RL (2006) $\delta$ subunit susceptibility variants E177A and $\mathrm{R} 220 \mathrm{H}$ associated with complex epilepsy alter channel gating and surface expression of $\alpha 4 \beta 2 \delta$ $\mathrm{GABA}_{\mathrm{A}}$ receptors. J Neurosci 26:1499-1506.

Gallagher MJ, Song L, Arain F, Macdonald RL (2004) The juvenile myoclonic epilepsy $\mathrm{GABA}_{\mathrm{A}}$ receptor $\alpha 1$ subunit mutation $\mathrm{A} 322 \mathrm{D}$ produces asymmetrical, subunit position-dependent reduction of heterozygous receptor currents and $\alpha 1$ subunit protein expression. J Neurosci 24:5570-5578.

Gallagher MJ, Shen W, Song L, Macdonald RL (2005) Endoplasmic reticulum retention and associated degradation of a $\mathrm{GABA}_{\mathrm{A}}$ receptor epilepsy mutation that inserts an aspartate in the $\mathrm{M} 3$ transmembrane segment of the alpha 1 subunit. J Biol Chem 280:37995-38004.

Gallagher MJ, Ding L, Maheshwari A, Macdonald RL (2007) The GABA receptor alphal subunit epilepsy mutation $\mathrm{A} 322 \mathrm{D}$ inhibits transmembrane helix formation and causes proteasomal degradation. Proc Natl Acad Sci U S A 104:12999-13004.

Gong Q, Keeney DR, Robinson JC, Zhou Z (2004) Defective assembly and trafficking of mutant HERG channels with C-terminal truncations in long QT syndrome. J Mol Cell Cardiol 37:1225-1233.

Hampton RY (2000) ER stress response: getting the UPR hand on misfolded proteins. Curr Biol 10:R518-R521.

Harkin LA, Bowser DN, Dibbens LM, Singh R, Phillips F, Wallace RH, Richards MC, Williams DA, Mulley JC, Berkovic SF, Scheffer IE, Petrou S (2002) Truncation of the $\mathrm{GABA}_{\mathrm{A}}$ )-receptor gamma2 subunit in a family with generalized epilepsy with febrile seizures plus. Am J Hum Genet 70:530-536.

Hirose S (2006) A new paradigm of channelopathy in epilepsy syndromes: intracellular trafficking abnormality of channel molecules. Epilepsy Res 70 [Suppl 1]:S206-S217.

Holbrook JA, Neu-Yilik G, Hentze MW, Kulozik AE (2004) Nonsensemediated decay approaches the clinic. Nat Genet 36:801-808.

Jensen TJ, Loo MA, Pind S, Williams DB, Goldberg AL, Riordan JR (1995) Multiple proteolytic systems, including the proteasome, contribute to CFTR processing. Cell 83:129-135.

Kananura C, Haug K, Sander T, Runge U, Gu W, Hallmann K, Rebstock J, Heils A, Steinlein OK (2002) A splice-site mutation in GABRG2 associated with childhood absence epilepsy and febrile convulsions. Arch Neurol 59:1137-1141.

Kang JQ, Macdonald RL (2004) The GABA receptor $\gamma 2$ subunit R43Q mutation linked to childhood absence epilepsy and febrile seizures causes retention of $\alpha 1 \beta 2 \gamma 2 \mathrm{~S}$ receptors in the endoplasmic reticulum. J Neurosci 24:8672-8677.

Kang JQ, Shen W, Macdonald RL (2006) Why does fever trigger febrile seizures? $\mathrm{GABA}_{\mathrm{A}}$ receptor $\gamma 2$ subunit mutations associated with idiopathic generalized epilepsies have temperature-dependent trafficking deficiencies. J Neurosci 26:2590-2597.

Klausberger T, Sarto I, Ehya N, Fuchs K, Furtmuller R, Mayer B, Huck S, Sieghart W (2001) Alternate use of distinct intersubunit contacts controls $\mathrm{GABA}_{\mathrm{A}}$ receptor assembly and stoichiometry. J Neurosci 21:9124-9133.

Kuzmiak HA, Maquat LE (2006) Applying nonsense-mediated mRNA decay research to the clinic: progress and challenges. Trends Mol Med 12:306-316.

Macdonald RL, Kang JQ, Gallagher MJ, Feng HJ (2006) GABA $_{\mathrm{A}}$ receptor mutations associated with generalized epilepsies. Adv Pharmacol 54:147-169.

Maquat LE (2004) Nonsense-mediated mRNA decay: splicing, translation and mRNP dynamics. Nat Rev Mol Cell Biol 5:89-99.

Mezghrani A, Monteil A, Watschinger K, Sinnegger-Brauns MJ, Barrère C, Bourinet E, Nargeot J, Striessnig J, Lory P (2008) A destructive interaction mechanism accounts for dominant-negative effects of misfolded mutants of voltage-gated calcium channels. J Neurosci 28:4501-4511.

Miesenböck G, De Angelis DA, Rothman JE (1998) Visualizing secretion and synaptic transmission with $\mathrm{pH}$-sensitive green fluorescent proteins. Nature 394:192-195.

Page KM, Heblich F, Davies A, Butcher AJ, Leroy J, Bertaso F, Pratt WS, Dolphin AC (2004) Dominant-negative calcium channel suppression by truncated constructs involves a kinase implicated in the unfolded protein response. J Neurosci 24:5400-5409.

Rajan RS, Kopito RR (2005) Suppression of wild-type rhodopsin maturation by mutants linked to autosomal dominant retinitis pigmentosa. J Biol Chem 280:1284-1291.

Rao RV, Ellerby HM, Bredesen DE (2004) Coupling endoplasmic reticulum stress to the cell death program. Cell Death Differ 11:372-380.

Schweizer C, Balsiger S, Bluethmann H, Mansuy IM, Fritschy JM, Mohler H, Lüscher B (2003) The gamma 2 subunit of GABA(A) receptors is required for maintenance of receptors at mature synapses. Mol Cell Neurosci $24: 442-450$

Verrall S, Hall ZW (1992) The N-terminal domains of acetylcholine receptor subunits contain recognition signals for the initial steps of receptor assembly. Cell 68:23-31.

Wallace RH, Marini C, Petrou S, Harkin LA, Bowser DN, Panchal RG, Williams DA, Sutherland GR, Mulley JC, Scheffer IE, Berkovic SF (2001) Mutant GABA(A) receptor gamma2-subunit in childhood absence epilepsy and febrile seizures. Nat Genet 28:49-52.

Ward CL, Omura S, Kopito RR (1995) Degradation of CFTR by the ubiquitin-proteasome pathway. Cell 83:121-127. 